\title{
PALEOBIOGEOGRAPHY OF SOUTHERN HEMISPHERE DECAPOD CRUSTACEA
}

\author{
RODNEY M. FELDMANN ${ }^{1}$ AND CARRIE E. SCHWEITZER ${ }^{2}$ \\ ${ }^{1}$ Department of Geology, Kent State University, Kent, Ohio 44242, < rfeldman@kent.edu> and 2Department of Geology, \\ Kent State University Stark Campus, Canton, Ohio 44720, <cschweit@kent.edu>
}

\begin{abstract}
Paleobiogeographic patterns of decapod crustaceans from the Southern Hemisphere, based upon 441 species-level records arrayed in 154 genera, document global patterns of distribution that can be compared to those previously published on decapods from the North Pacific and Central American regions. All known records of decapods from the Southern Hemisphere spanning the Early Triassic to Pleistocene have been compiled, nearly all have been personally verified, and patterns of origin and distribution have been interpreted. Interchange between hemispheres, including amphitropical and bipolar distributions, are recognized from Jurassic to postMiocene time. The high southern latitudes was a site of origin of several generic-level taxa during the Jurassic through Eocene and many of these taxa have been identified in subsequent times in lower latitude regions in shallow- and deepwater environments in both hemispheres. The isolation of Antarctica due to ocean currents significantly diminished the role of the high southern latitudes as an area of origin for decapods. The Tethys was an important dispersal pathway for decapods during the Cretaceous through early Miocene. Endemism was high during the Eocene, similar to the North Pacific and Central America. The magnitude of the Cretaceous/Paleogene extinction event on the Southern Hemisphere decapod fauna was not profound; most Cretaceous extinctions seem to have occurred well before the end of the Cretaceous, and $85 \%$ of the Cretaceous families are known from the Paleogene in the Southern Hemisphere taxa.
\end{abstract}

Note: Tables 1 and 2, listing the species records from the Southern Hemisphere and the tropical Western Hemisphere (Table 1) and the geographic distribution of genera from the study area arrayed by geological time and family within time intervals (Table 2), are posted on the Journal of Paleontology's Supplemental Database, www.journalofpaleontology.org.

\section{INTRODUCTION}

$\mathrm{F}$ OSSIL DECAPOD Crustacea have been noted in the Southern Hemisphere for over 150 years. One of the earliest accounts is that of d'Orbigny (1842) in South America, and shortly thereafter, Darwin (1842) also noted the presence of decapod fossils there. Additional observations of fossil decapods, most in the form of descriptions of single species, were published throughout the remainder of the nineteenth century. However, as late as the midtwentieth century, the number of occurrences was small enough that the most prominent systematist working with fossils, Martin Glaessner, did not attempt a paleobiogeographic synthesis.

The study of decapod paleontology in the Southern Hemisphere has been sporadic and most discoveries of fossil decapods have probably been incidental to stratigraphic work or collection of other taxa. Nonetheless, in the past two decades, an increase in interest in the group in the Southern Hemisphere has led to much more intensive collecting in Antarctica, southern South America, New Zealand, and to some extent Australia. Several summary papers cited throughout this work have drawn together the information and have provided a database adequate for evaluation.

Thus, interest in the study of fossil shrimp, crabs, and lobsters in the Southern Hemisphere has increased to the point that it is now possible to summarize the occurrences of 441 species records arrayed in 154 genera, record the occurrences of congeners in other regions of the world, define stratigraphic ranges for these genera, and suggest a paleobiogeographic synthesis. These are the central purposes of this work.

\section{PALEOBIOGEOGRAPHY}

Overview and caveats.-The scope of this paleobiogeographic summary requires some explanation. Previous summaries of paleobiogeography have focused on the high southern latitudes (Feldmann, Aguirre-Urreta et al., 1997), the North Pacific (Schweitzer, 2001), and the tropical and subtropical Americas (Schweitzer et al., 2002). In order to compile data to link these studies to that of the entire Southern Hemisphere, records from the Caribbean region, all of South America, Africa south of the equator, Australia, New Zealand, India, Antarctica, and Madagascar have been compiled. In so doing, there is some overlap in records from previous studies, but that was judged acceptable to assure the most complete coverage possible. Furthermore, it is clear and obvious that, as a result of plate motions in the Cenozoic and Mesozoic, considerable repositioning of the areas under discussion has taken place. The implications of those changes will be discussed below. Because of the manner in which the localities of taxa have been reported in the literature, their geographic occurrences are arranged with reference to modern political boundaries in Table 1. However, their paleobiogeographic position has been noted in reference to paleolatitude in Table 2 to reflect more accurately their historical positions.

Few decapod fossil localities on the landmasses currently situated primarily in the Southern Hemisphere have been known until recently and, therefore, the number of decapods fossil records has been limited. This lack of occurrences is due to the relative paucity of studies in the Southern Hemisphere and to the limited land area in the Southern Hemisphere as compared to that in the Northern Hemisphere. With regard to the former observation, a surge in collecting activity in the past 20 years has resulted in a large increase in the number of known sites. The paleogeographic maps (Figs. 1-3) show the positions of sites yielding decapod fossils in the study area. The number of genera reported in the compilation herein totals 154 . Table 1 lists the species known from the study area, arrayed by geologic time and geographical location. Table 2 records the genera known from the study area and notes the worldwide distribution of their occurrences, arrayed by geologic time. Figure 4 shows the worldwide geologic ranges of the genera.

The asymmetry of distribution of land masses in the Northern and Southern hemispheres results in there being a smaller area in which to seek fossil decapods in the Southern Hemisphere. Another consequence of a smaller area is that, whereas the exposure of fossiliferous rocks in the Northern Hemisphere is biased in favor of epicontinental seaways, most Southern Hemisphere sites are rather near continental margins. The result of this difference is that many families of decapods that are well represented in epicontinental regions are poorly represented, or absent altogether, in marginal marine areas. Conversely, many families commonly 

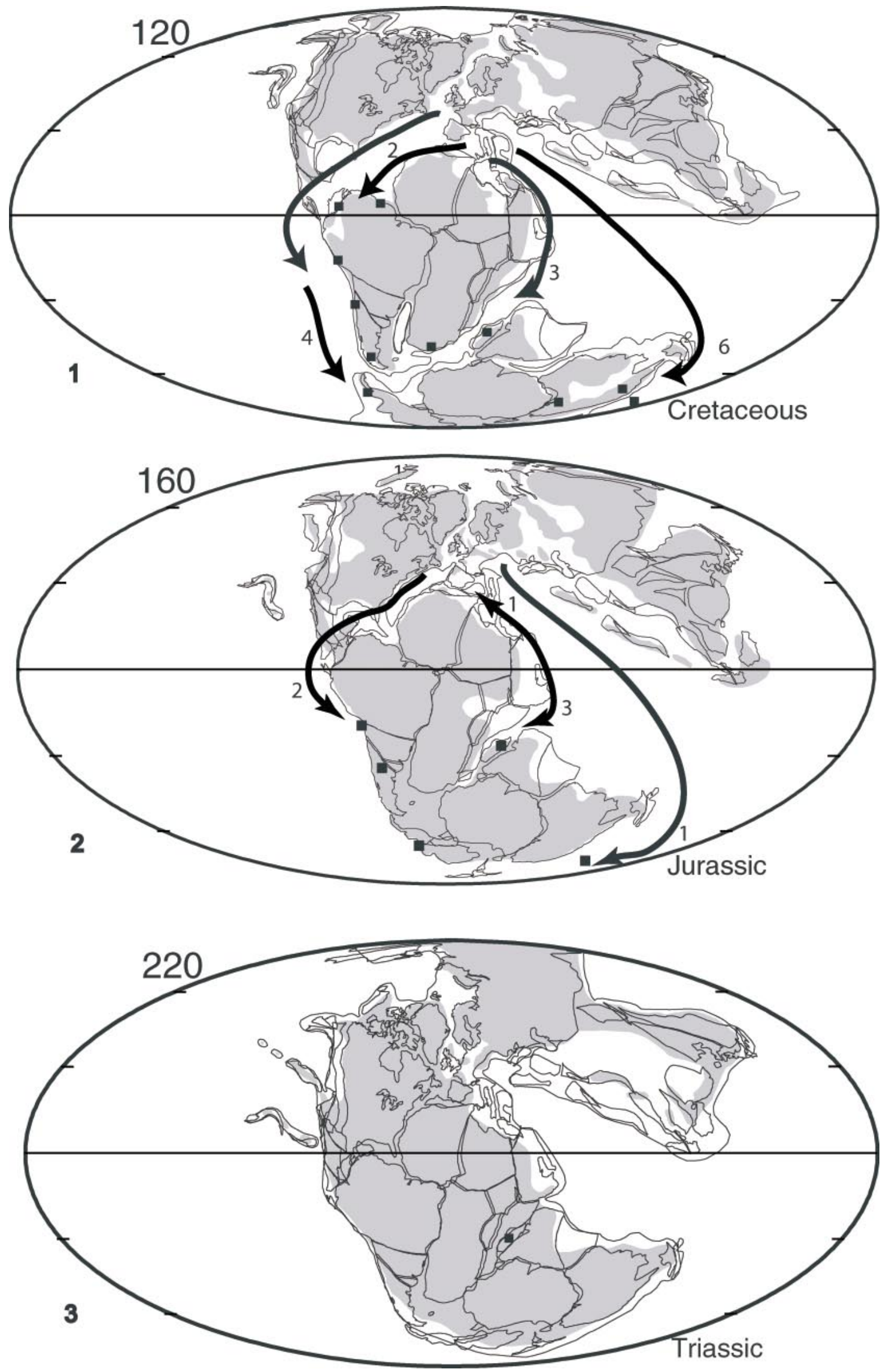
found in shallow-water settings near continental margins are underrepresented, or absent, in epicontinental settings.

Clearly, the strength of the interpretations regarding areas of origin and paleobiogeographic distributional patterns are only as good as the available data. Addition of new data will undoubtedly result in revision of some of the patterns. Similarly, the paleobiogeographic patterns might be thought of as more rigorous if they had been subjected to cladistic analysis, such as that described by Lieberman (2002). That is the ultimate goal of this research; however, it is not possible to generate meaningful results at this time for two reasons. The Decapoda is a very large group and subjecting the entire order to cladistic analysis has not been accomplished, but part of that work is currently being done by the authors and others. In addition, although knowledge of the fossil record of Southern Hemisphere decapods is vastly more robust than in the past, 441 species-level records arrayed in 154 genera distributed over half the earth cannot be considered sufficient to generate meaningful area cladograms (Lieberman, 2002).

Definitions. - Throughout this work we have attempted to use a uniform terminology for the areas under study. The definitions are as follows:

Tropical. The region lying between $23 \frac{1}{2}^{\circ}$ North and $23 \frac{1}{2} 2^{\circ}$ South. Subtropical. The regions lying between $2312^{\circ}$ and $30^{\circ}$ South or North.

Southern extratropical. The region lying between $30^{\circ}$ and $90^{\circ}$ South.

Temperate. The regions lying between $30^{\circ}$ and $60^{\circ}$ South or North.

High Southern Latitudes. The region between $60^{\circ}$ and $90^{\circ}$ South.

Because of plate motions, some of the collecting sites may have occupied a temperate latitudinal position during one time interval and a subtropical or tropical latitudinal position during a subsequent time interval. For example, New Zealand occupied a high southern latitudinal position prior to the Oligocene and a temperate latitudinal position from the Oligocene to the present. Biogeographic distributions of decapods from New Zealand are recorded accordingly.

One oceanographic condition that was not considered was that of the asymmetry of circulation patterns that results in the broader latitudinal range of warm water regions on the west sides of oceans compared to that on the eastern sides. Although the pattern surely existed throughout the time intervals under consideration, the circulation pattern was not considered because of the uncertainty of its magnitude.

The tallies of genera and species are affected by biological judgments regarding Callianassa Leach, 1815a. Callianassa spp. sensu lato are widespread in fossil deposits and several occurrences are noted in the list of species from the Southern Hemisphere (Table 1). However, Manning and Felder (1991) demonstrated that, although several genera could be recognized on the basis of morphology of the proximal elements of the first pereiopods, the hands and fingers alone provided very little evidence as to their generic identity. Therefore, throughout the work, Callianassa sp. were counted as species occurrences, but the genus Callianassa was not included in generic counts. Throughout the work, species counts are based upon occurrences so that the same species from two different localities would be counted as two occurrences. Other callianassids, such as Protocallianassa Beurlen, 1930, were included in generic counts because their identity was certain. In similar fashion, genera within the Paguridae, the hermit crabs, are listed in Table 1 and counted as species occurrences but are not noted in Table 2 and are not counted in generic counts because of the difficulty in assigning generic names to their fragmentary remains.

Triassic.-The discovery of two new species of decapods from Lower Triassic rocks in Madagascar (Garassino and Teruzzi, 1995; Garassino and Pasini, 2002) brings to three the total number of Triassic decapods, all penaeids, from Madagascar. Van Straelen (1933) had previously described a new species of shrimp from there. Together they constitute the only records of Triassic decapods in the Southern Hemisphere. During the Triassic, Madagascar lay at a latitude of about $30^{\circ} \mathrm{S}$ (Fig. 1.3). These genera are known from no other area and thus provide little information about relationships with shrimp elsewhere in the world.

Jurassic.-Jurassic decapods are known from Chile and Madagascar, which were located in subtropical latitudes; and from New Zealand and Antarctica, at latitudes above $60^{\circ} \mathrm{S}$. A total of 12 species-level occurrences arrayed in nine genera are known from Southern Hemisphere occurrences (Fig. 1.2). Of the three genera in the high southern latitudes, Antarcticheles Aguirre-Urreta et al., 1990 is known only from its occurrence in Antarctica (Aguirre-Urreta et al., 1990); Trachysoma Bell, 1858 had its origin in either the North Atlantic or the high southern latitudes; and Mecochirus Germar, 1827 had its earliest occurrence in the North Atlantic in Sinemurian time but radiated into the Southern Hemisphere by the Toarcian (Förster, 1971) as did Glyphea von Meyer, 1835, in the temperate southern latitudes. Mecochirus is also known from Madagascar (Secretan, 1964) and Chile (Förster and von Hillebrandt, 1984) in the Jurassic, both of which were at subtropical paleolatitudes. Of the genera known from the subtropics of the Southern Hemisphere Jurassic (Madagascar), Erymastacus Beurlen, 1928 had a broad distribution in the Early Jurassic of Canada and Europe, ranging from Europe into East Africa by the Late Jurassic (Glaessner, 1969); Phlyctisoma Bell, 1863 had its earliest occurrence in Madagascar (Secretan, 1964), subsequently radiating into the North Atlantic region; and Eryma von Meyer, 1840 and Coleia Broderip, 1835 appeared first in the North Atlantic and subsequently radiated into Madagascar (Secretan, 1964). Chilenophoberus Chong and Förster, 1976 is known only from Chile (Chong and Förster, 1976). All of the decapods found in Triassic and Jurassic rocks in the Central Americas appear to have had their originations in the North Atlantic (Schweitzer et al., 2002); and five of the Jurassic Southern Hemisphere decapods also originated apparently in the North Atlantic. Clearly, what is today the North Atlantic was an important region during the Jurassic for the origination of decapod taxa; alternatively, the historically detailed study of the North Atlantic region may have led to an overestimation of its importance.

Early Cretaceous.-The record of fossil decapods in the study area is relatively robust during the Early Cretaceous. A total of 54 species-level occurrences embraced within 27 genera have been recorded from numerous Southern Hemisphere localities. Thirteen genera are known from high southern latitude sites and 18 are known from temperate latitudes. No decapods are reported from the Central American region of South America during the

$\leftarrow$

FIGURE 1-Paleobiogeographic maps showing localities from which 1, Early Cretaceous, 2, Jurassic, and 3, Triassic decapods have been collected in the study area. Dispersal routes are inferred based upon timing of appearance of generic taxa worldwide. Numbers on the maps denote number of genera introduced into the area during the time interval. Generalized circulation patterns are plotted on map bases from Scotese (1997), and using paleocurrent data from Bice (personal commun. to RMF). 

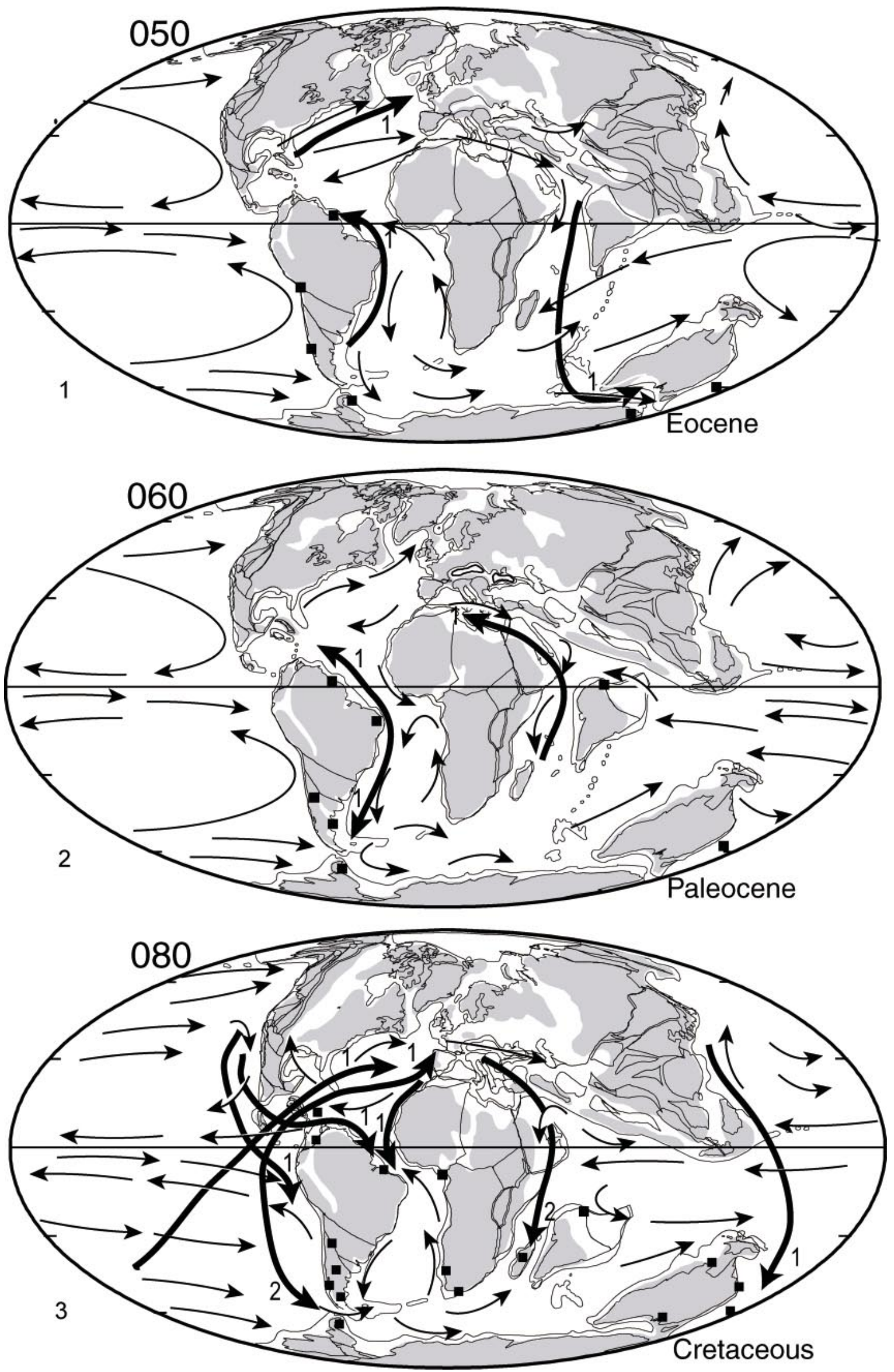
Early Cretaceous; five of the genera are known from both high southern and temperate latitudes. Of the total number of Early Cretaceous genera, 15 have their earliest records during the Early Cretaceous, but not all arose in the Southern Hemisphere. Of these 15 that arose during the Early Cretaceous, three dominant distributional patterns can be readily identified. Three of the genera originated in, and appear to have been endemic to, the southern tropical latitudes; six genera originated in the high southern latitudes; and four of the genera originated in the Northern Hemisphere and radiated southward. Two genera, Notopocorystes McCoy, 1849 and Hemioon Bell, 1863, occurred during this time interval in both hemispheres and, because of limited stratigraphic resolution, the area of origin cannot be determined unequivocally.

In the Central Americas, a few more than half of the genera originated within that region (Schweitzer et al., 2002), and about one-third originated in the North Atlantic (Schweitzer, 2001). Thus, there seems to have been little interchange between the extratropical Southern Hemisphere region and the Central Americas, while the North Atlantic region contributed to both the Central American decapod fauna and the extratropical Southern Hemisphere fauna. Perhaps temperature and/or depth preferences among the genera explain this pattern.

Within the Southern Hemisphere tropical and subtropical region, four genera, Araripecarcinus Martins-Neto, 1987, Beurlenia Martins-Neto and Mezzalira, 1991a, Brazilomunida Martins-Neto, 2001, and Maurimia Martins-Neto, 2001, are known from single localities (Martins-Neto, 1987, 2001; Martins-Neto and Mezzalira, 1991a, 1991b) and provide no biogeographical insights. Occurrences of Necrocarcinus? Bell, 1863 in Colombia (Rathbun, 1937) and Mecochirus in Chile document dispersal of North Atlantic taxa into the tropical region.

Southern Hemisphere temperate latitude decapods are known from the Early Cretaceous in Chile, Argentina, South Africa, and Madagascar. None of the genera recorded from those areas originated in, or were endemic to, that region, and some also occurred in high southern latitude localities as well. Hoploparia McCoy, 1849 was widespread during the Early Cretaceous and has been recorded in Argentina (Aguirre-Urreta, 1989), Madagascar (Secretan, 1964), and in the high latitude region of Australia (Etheridge, 1917). Similarly, Glyphea von Meyer, 1835 is known from Argentina (Aguirre-Urreta, 1989) at midlatitudes and from high latitude sites in Antarctica (Taylor, 1979) and Australia (Etheridge, 1917; Woods, 1957). A third broadly distributed genus is $\mathrm{Pa}$ laeastacus Bell, 1850. This genus has been recognized in Argentina at midlatitudes (Aguirre-Urreta and Ramos, 1981) as well as the high latitude sites of Antarctica (Taylor, 1979) and Australia (Etheridge, 1914). These genera, as well as Enoploclytia McCoy, 1849, known from Argentina (Aguirre-Urreta, 1982) and Antarctica (Taylor, 1979); Meyeria McCoy, 1849, from Argentina (Harbourt, 1905) and Madagascar (Kitchin, 1908); Paranecrocarcinus Förster, 1968, from South Africa (Wright, 1997) and Madagascar (Förster, 1970); and Astacodes Bell, 1863, from Australia (Woods, 1957), are all taxa whose first occurrences are in the Northern Hemisphere. The pathways of dispersal are not clear but parsimonious pathways are suggested (Fig. 1.1). Notopocorystes, known from early Cretaceous rocks in Madagascar (Secretan, 1964), is also known from the North Atlantic region during that time, and its area of origin is not clear.

The remaining genera from the region were all high latitude endemic genera during the Early Cretaceous. They include Tillocheles Woods, 1957; Torynomma Woods, 1953; Oonoton Glaessner, 1980; Dioratiopus Woods, 1953; and Lignihomola Collins, 1997, all from Australia (Woodward, 1892; Woods, 1953, 1957; Glaessner, 1980), and Trachysoma and Schlueteria Fritsch in Fritsch and Kafka, 1887, from Antarctica (Taylor, 1979). Thus, as early as the Early Cretaceous the southern high latitudes area was a region in which a substantial number of decapod genera originated and some of them, Torynomma, Trachysoma, and Schlueteria, subsequently dispersed into Northern Hemisphere sites. This pattern of southern high latitude origin of decapods taxa was first recognized in the dispersal pattern of Eocene taxa (Zinsmeister and Feldmann, 1984).

Late Cretaceous.-During the Late Cretaceous, 88 records of species (Table 1) arrayed in 41 genera (Table 2) have been recorded. Some of the species records are duplicates in the sense that the same species may have been recorded at different localities or in different stages. Thirty-six of the genera occurred in southern extratropical localities and eight genera were recorded from tropical localities. Sixteen of the genera had their origins in the study area and were endemic to the area during this time interval. In the paleotropics in the Southern Hemisphere, Ophthalmoplax Rathbun, 1935; Xanthosia Bell, 1863; Cretacoranina Mertin, 1941; Carcineretes Withers, 1922; and Galathea Fabricius, 1793 are known from no other regions during the Late Cretaceous (Beurlen, 1958b; Morris, 1993; Feldmann et al., 1999; Feldmann and Villamil, 2002; Schweitzer et al., 2002), and all except Ophthalmoplax originated during this time interval. The latter genus arose in the Early Cretaceous in the Central American region. Two other genera, Ranina? Lamarck, 1801 and Penaeus? Fabricius, 1798, from Pakistan may represent first occurrences of those genera in the fossil record. The former genus is probably correctly assigned and the latter is highly questionable; however, neither identity can be confirmed until the original material is examined. The site of origin of Costacopluma Collins and Morris, 1975 is problematic. The genus appeared in Nigeria during the late Campanian (Collins and Morris, 1975) and in northern India (Gaetani et al., 1983) and the Central American region during the Maastrichtian (Vega and Carmen Perrilliat, 1989; Vega and Feldmann, 1992), suggesting an origin for the genus in the Tethyan region. However, Vega and Feldmann (1992) suggested that Costacopluma had originated specifically in the Central American region as a derivative of the North American genus, Archaeopus Rathbun, 1908. Until additional information is available, it is prudent to consider the area of origin to be equivocal.

In the paleotemperate latitudes, Dioratiopus and Torynomma had arisen in Australia during the Early Cretaceous and remained endemic to that area in the Late Cretaceous (Glaessner, 1980). Dromiopsis Reuss, 1859; Secretanella Guinot and Tavares, 2001; and Ctenocheles Kishinouye, 1926 arose in the Late Cretaceous in the area of Madagascar and South Africa (Secretan, 1964); Eodorippe Glaessner, 1980 made its first appearance in Australia (Glaessner, 1980); Dynomenopsis Secretan, 1972 exhibited its sole occurrence in the Cenomanian of Bolivia (Secretan, 1972); and Lobulata Schweitzer et al., 2004 and Rocacarcinus Schweitzer, 2005 made their earliest known occurrences in Argentina (Feldmann et al., 1995; Schweitzer et al., 2004).

Seven genera originated in the high southern latitudes during

$\leftarrow$

FIGURE 2-Paleobiogeographic maps showing localities from which 1, Eocene, 2, Paleocene, and 3, Late Cretaceous decapods have been collected in the study area. Dispersal routes are inferred based upon timing of appearance of generic taxa worldwide. Numbers on the maps denote number of genera introduced into the area during the time interval. Generalized circulation patterns are plotted on map bases from Scotese (1997), and using paleocurrent data from Bice (personal commun. to RMF). 

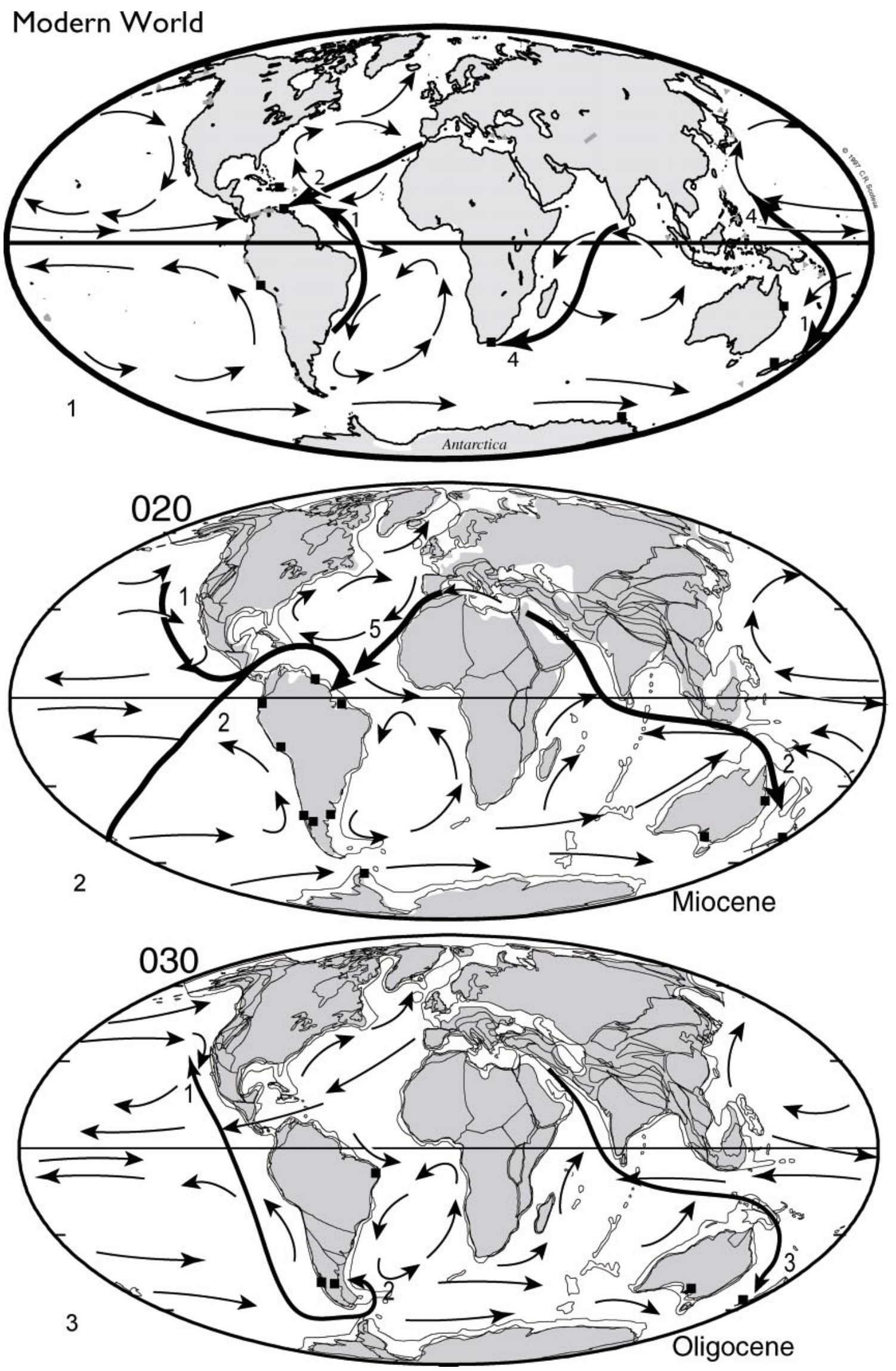
the Late Cretaceous. Haumuriaegla Feldmann, 1984 was first noted in marine rocks of New Zealand (Feldmann, 1984). The genus was an early marine member of what is now a lineage of living freshwater decapods, the aeglids, that inhabit streams in southern South America. Homolodromia A. Milne Edwards, 1880, first noted in the Late Cretaceous of New Zealand (Feldmann, 1993), subsequently was collected from Eocene rocks in Antarctica (Feldmann and Wilson, 1988), and is known from deepwater settings in modern seas. In Antarctica, five new genera appeared. Cristafrons Feldmann, Tshudy et al., 1993 and Retrorsichela Feldmann, Tshudy et al., 1993 were endemic to the region (Feldmann, Tshudy et al., 1993) and are known from no other time interval. Rhinopoupinia Feldmann, Tshudy et al., 1993, known only from the Late Cretaceous of Antarctica (Feldmann, Tshudy et al., 1993), is the earliest known member of a small family of deepwater decapods extant in the South Pacific, the Poupiniidae Guinot, 1991. Metanephrops Jenkins, 1972a and Munidopsis Whiteaves, 1874 are the progenitors of extant genera known from lower latitude localities (Feldmann, 1989; Feldmann, Tshudy et al., 1993). Thus, the pattern of high latitude origin of taxa first noted in the Early Cretaceous continued in the Late Cretaceous.

Interchange of genera across the equator was also a major factor in the generic composition of Southern Hemisphere faunas during the Late Cretaceous (Fig. 2.3). The North Pacific was the site of origin of two genera, Eodorippe and Homolopsis Bell, 1863, the former dispersing into Australia (Schweitzer, 2001), and the latter dispersing into the temperate latitudes of Chile and Australia (Glaessner, 1980; Förster and Stinnesbeck, 1987). These records are the first contribution of North Pacific taxa into the Southern Hemisphere. North Atlantic contributions to the study area included the introduction of Astacodes and Cyclothyreus Remeš, 1895 into the Central American region (Beurlen, 1965; Schweitzer et al., 2002); Titanocarcinus A. Milne Edwards, 1864 and Linuparus White, 1846 into Madagascar and South Africa at temperate latitudes (Secretan, 1964); and Linuparus and Plagiophthalmous Bell, 1863 into the high southern latitudes in Antarctica (Tshudy and Feldmann, 1988; Feldmann, Tshudy et al., 1993). Linuparus is also known from Cameroon at paleotropical latitudes (Glaessner, 1932). Hemioon, which first appeared in New Zealand in the Early Cretaceous, dispersed northward into southern North America in the Central American region (Schweitzer et al., 2002), and Schlueteria, first noted in the Early Cretaceous of Antarctica, dispersed into the area of Madagascar and into the North Atlantic region during the Late Cretaceous (Secretan, 1964). Necrocarcinus is known from Late Cretaceous localities in Antarctica (Feldmann, Tshudy et al., 1993), dispersing to the region from the North Atlantic, possibly via the Central Americas (Rathbun, 1937).

In spite of this interchange, it is interesting that nearly $70 \%$ of the Late Cretaceous decapods in the Central American region appear to have originated in that area, and $15 \%$ of the remainder originated in what is today the North Atlantic. Apparently, most of the interchange was from north to south, not south to north.

Paleocene.-Eighteen species-level records arrayed in 16 genera of Paleocene decapods have been recorded from the study area. Glyphithyreus Reuss, 1859, its first occurrence, and Goniocypoda Woodward, 1867 are known from the paleotropics of Pakistan (Collins and Morris, 1978). Costacopluma is known in the paleotropical region of Venezuela (Collins et al., 1994) and
Brazil (Feldmann and Martins-Neto, 1995) as well as in the paleotemperate region of southern Argentina. Lobulata, Rocacarcinus, Chirinocarcinus Karasawa and Schweitzer (2004), and Ctenocheles were confined to the paleotemperate region in Argentina (Feldmann et al., 1995; Schweitzer et al., 2004). Metanephrops is known from high southern latitudes in Antarctica (Feldmann, Tshudy et al., 1993), Glyphea has been described from New Zealand (Feldmann, 1993), Linuparus is known from Chile (Feldmann, Tshudy et al., 1993), and Hoploparia has been recognized in Antarctica (Feldmann, Tshudy et al., 1993) and Argentina (Aguirre-Urreta, 1989). The first known occurrences of Chirinocarcinus, Palaeopinnixa Via, 1966, and Proterocarcinus Feldmann et al., 1995 are from Paleocene rocks of Argentina and all but Palaeopinnixa remained endemic to the area.

Although only two of these generic occurrences are new to the study area, there were some significant dispersal events (Fig. 2.2). Costacopluma, which had been known from the Central America region and the Tethys in the Late Cretaceous, dispersed into southern Argentina in the Paleocene. Dromiopsis, which had been known in Madagascar during the Late Cretaceous, appeared in the North Atlantic region in the Paleocene. The limited information on dispersal, as with the limited number of Paleocene taxa, is partially due to collecting bias. Relatively little collecting has been done in central South America, South Africa, and Australia. Undoubtedly, additional field work will yield additional information.

The paucity of Paleocene decapod records is also related to available exposures of rock of this age. As in other parts of the world, the Paleocene record in the Southern Hemisphere pales in comparison to that of the Late Cretaceous and the Eocene. Because this was a time of general lowstand of sea level, particularly during the Danian (Vail et al., 1977), and because the Eocene was a time of relative highstand of sea level, the areal extent of $\mathrm{Pa}$ leocene rocks is limited. As a result, marine Paleocene rocks tend to be confined to small, narrow exposures between much more extensive exposures of Upper Cretaceous and Eocene rocks. Because there is a relationship between area of exposure of rocks and number of taxa (Raup, 1976), the diversity of Paleocene decapods is probably underestimated. The extent to which this limited number of Paleocene taxa results from the Cretaceous extinction will be discussed below.

Eocene.-The pattern of Eocene decapod distribution in the study area is based upon 43 species-level records arrayed in 31 genera. Two of the genera, Calappilia A. Milne Edwards, 1873 and Falconoplax Van Straelen, 1933 are confined to the Central American, paleotropical area. Palaeopinnixa occurs in the study area, having dispersed northward from its site of first occurrence in the Paleocene of Argentina. In the extratropical, temperate southern latitudes, Imaizumila Karasawa, 1993, the first occurrence of that genus, is confined to that region, and Lyreidus de Haan, 1841 occurs in the southern temperate region as well as in New Zealand and Antarctica in the high southern latitudes.

It is in the high southern latitudes that the preponderance of Eocene occurrences is found. Twenty-five genera are known from that region and, of these, 10 represent first occurrences of the genera. Localities on the Antarctic Peninsula (Feldmann and Zinsmeister, 1984a, 1984b; Feldmann and Wilson, 1988; Feldmann et al., 2003) and the South Island of New Zealand (Feldmann and Keyes, 1992) each yielded five first occurrences. It is noteworthy

FIGURE 3-Paleobiogeographic maps showing localities from which 1, Post-Miocene, 2, Miocene, and 3, Oligocene decapods have been collected in the study area. Dispersal routes are inferred based upon timing of appearance of generic taxa worldwide. Numbers on the maps denote number of genera introduced into the area during the time interval. Generalized circulation patterns are plotted on map bases from Scotese (1997), and using paleocurrent data from Bice (personal commun. to RMF). 


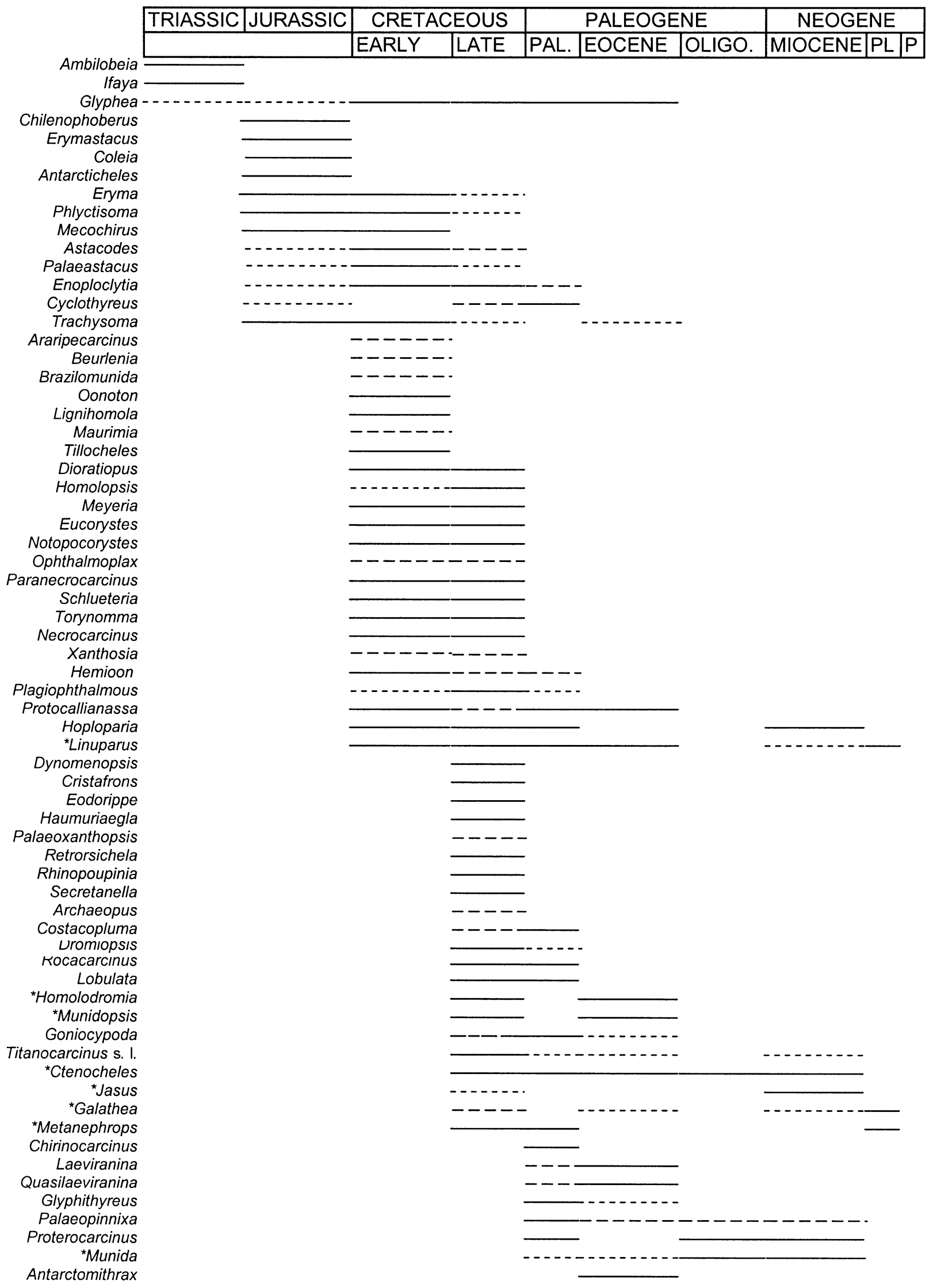

FIGURE 4 
Pakicarcinus

Pororaria

${ }^{\star}$ Chasmocarcinus

*Menippe

Calappilia

Eoinachoides

Eriosachila

Falconoplax

Imaizumila

Lobocarcinus

Maeandricampus

Tumidocarcinus

Typibolus

*Notomithrax

*Panopeus

${ }^{*}$ Parthenope

${ }^{*}$ Portunus

${ }^{*}$ Raninoides

${ }^{*}$ Callianopsis

${ }^{*}$ Callinectes

*Leptomithrax

*Lyreidus

*Ommatocarcinus

${ }^{*}$ Carcinoplax

${ }^{*}$ Callichirus

*Calappa

*Scylla

${ }^{*}$ Cancer s.l.

Baricarcinus

Lammuastacus

Propalaemon

Pseudocaridinella

*Tutankhamen

Bechleja

*Leurocyclus

Necronectes

Notocarcinus

${ }^{*}$ Asthenognathus

${ }^{*}$ Chaceon

*Penaeus

${ }^{*}$ Dagnaudus

${ }^{\star}$ Euphylax

*Hepatus

*Trichopeltarion

${ }^{\star}$ Charybdis

*Atergatis

*Metacarcinus

*Pilumnus

Actinotocarcinus

Antarctidromia

Cyclocancer

Miograpsus

*Naxia

Paranephrops

Paratumidocarcinus

${ }^{*}$ Acanthocarpus

*Hepatella

*Osachila

*Parolomis

*Persephona

*Pseudorhombila

*Randallia

*Schizophroida

*Sesarma

${ }^{*}$ Rochinia

*Pseudocarcinus

*Maja

${ }^{*}$ Romaleon

*Ocypode

FIgURE 4-Continued.

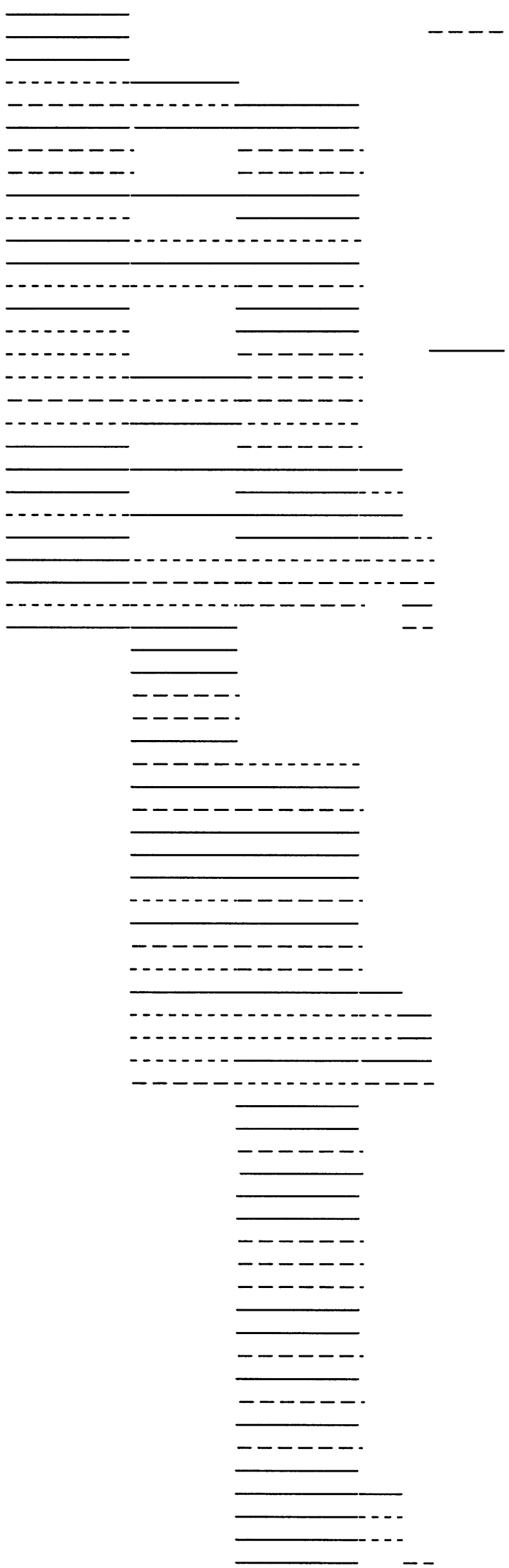




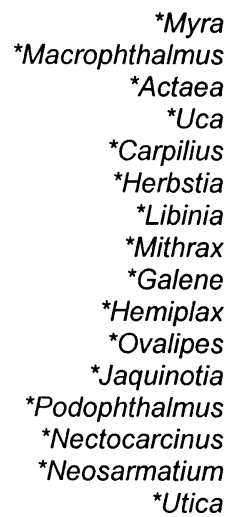

FigURE 4-Continued. Stratigraphic distribution of decapod genera known from the study area. Solid lines denote occurrences within the temperate and high latitude regions of the Southern Hemisphere. Long broken lines denote occurrences within tropical and subtropical regions of the study area. Short broken lines denote occurrences of genera in parts of the world outside the study area. Data from Tables 1 and 2 . Asterisks (*) denote genera with extant representatives.

that only two of the genera, Antarctomithrax Feldmann, 1994 and Micromithrax Noetling, 1881, are represented by sole occurrences. All the other taxa either dispersed into other regions during the Eocene or have occurrences outside of the high southern latitudes in subsequent epochs. Seventeen have extant species. Although these figures for numbers of genera in various parts of the Southern Hemisphere are undoubtedly skewed toward the high southern latitudes because of the intensity of field work in Antarctica and New Zealand, it remains that this was a time of major origination of new taxa in the high southern latitudes that led to radiation of the taxa into other, more temperate regions of the world ocean (Fig. 2.1).

It is also significant that, although many new taxa evolved worldwide during the Eocene, many of them were endemic to their regions of origin during the Eocene. Of the Southern Hemisphere occurrences, Pakicarcinus Schweitzer et al., 2004 dispersed from the Tethyan region of Pakistan into Australia during the Eocene. Laeviranina Lőrenthey and Beurlen, 1929 and Quasilaeviranina Tucker, 1998, whose points of origin are unclear, had a very broad distribution in the Eocene and dispersed as far southward as New Zealand during that epoch, probably via the Tethys. Palaeopinnixa dispersed from the Southern Hemisphere to the North Pacific region during the Eocene. Two Eocene taxa that had originated in the high southern latitudes during the Cretaceous remained endemic to extratropical Southern Hemisphere, and Ctenocheles originated in the temperate southern latitudes during the Cretaceous and remained in that general area as well as dispersing nearly worldwide during the Eocene. The observations regarding the generally high degree of endemism in the Southern Hemisphere parallel the patterns previously observed in the North Pacific (Schweitzer, 2001) and the Central American region (Schweitzer et al., 2002).

Oligocene.-A total of 24 genera have been recorded in the study area, based upon 32 species-level records. Three of the genera have been noted in the Central American paleotropical region, all of which have their origins in Brazil. Both Bechleja Houša, 1956 and Propalaemon Woodward, 1903 have ranges that extend beyond the occurrence in the Oligocene of Brazil. The remaining 20 genera are known from paleotemperate regions. In Argentina, eleven genera are reported; two genera are reported in Chile; four are noted in Australia; and six genera are noted in New Zealand. Two genera from Argentina, Baricarcinus Casadío et al., 2004 and Lammuastacus Aguirre-Urreta, 1992, are reported from single occurrences in that region and are known from no other occurrences in subsequent epochs. These generic records include seven first occurrences in Argentina, two in Australia, and one in Brazil. The large number of first occurrences in the Southern Hemisphere, about $42 \%$, exceed that in the North Pacific (Schweitzer, 2001) and the Central American regions (Schweitzer et al., 2002). This high number is largely attributed to descriptions of decapods from remarkably fossiliferous localities in Australia (Jenkins, 1985) and Argentina (Casadío et al., 2004).

Chaceon Manning and Holthuis, 1989, a genus that includes several living species, originated in the Oligocene of Argentina and is also known from Chile. Previously, Chaceon was reported to have originated in the Eocene (Casadío, Feldmann et al., 2000; Schweitzer and Feldmann, 2000b), based upon ${ }^{40} \mathrm{Ar} /{ }^{39} \mathrm{Ar}$ dating of a volcanic ash within the Centinela Formation; however, subsequent dating of mollusk shells in the formation provides strong evidence for an Oligocene age (Casadío, Guerstein et al., 2000).

Relatively little faunal interchange occurred between the Northern and Southern hemispheres during the Oligocene (Fig. 3.3). Six genera that originated in the Southern Hemisphere prior to the Oligocene remained there. Munida Leach, 1820 and Callianopsis de Saint Laurent, 1973, which had Eocene origins in the North Pacific region, are recorded in the Oligocene of Argentina. Calappa Weber, 1795, which first occurred in the high southern latitudes, dispersed into Mexico during the Oligocene (Schweitzer et al., 2002). Three genera, Menippe de Haan, 1833, Portunus Weber, 1795, and Ommatocarcinus White, 1852, whose origins were in the Tethyan region during the Eocene, made their first occurrence in the fossil record of the Southern Hemisphere in the Oligocene of New Zealand.

Absence of high southern latitude occurrences in Antarctica results from two factors. Isolation of the continent by development of the circum-Antarctic current system near the end of the Eocene rendered the paleoenvironment more harsh than it had been in the Eocene. Furthermore, there is a general absence of Oligocene rocks in the region.

Miocene.-The Miocene record of fossil decapods is rich. Sixty-two genera have been reported from the study area, based upon 93 species-level records. Twenty-seven of the genera are recorded in the paleotropical region at localities in Brazil, Venezuela, Trinidad, Barbados, Ecuador, and Peru; 41 genera, including four that also occurred in the tropical region, are known from temperate latitudes in Argentina, Chile, Australia, and New Zealand; and two genera are known from a southern high latitude site on King George Island, Antarctica. In the polar region, Antarctidromia Förster et al., 1985, which is a genus within the extant Homolodromiidae, is known from no other locality. Hoploparia, well 
known in the Cretaceous and Paleogene, is present in the Antarctic as the last relict of that genus. Twelve genera made first occurrences in the temperate southern latitudes during the Miocene, and six made first occurrences in the Central American Southern Hemisphere region.

The Miocene was a time of considerable interchange of taxa between the hemispheres (Fig. 3.2). Five genera, Typibolus Stoliczka, 1871; Scylla de Haan, 1833; Hepatus Latreille, 1802; Penaeus Fabricius, 1798; and Parthenope Weber, 1795 appeared in the Central American area in the Miocene. These genera were known previously from the region of the Tethys. Portunus, known from the Oligocene of New Zealand, and Callinectes Stimpson, 1860, known from the Eocene of Antarctica, also appeared in the Caribbean during the Miocene. Another addition to the Caribbean fauna at this time was Panopeus H. Milne Edwards, 1834, whose origin was in the North Pacific. Finally, Jasus Parker, 1883 and Lobocarcinus Reuss, 1857 appeared in New Zealand during the Miocene, derived from rootstock in the Tethys. One probable explanation for this increase in interchange between hemispheres lies in the climatic amelioration during the Middle Miocene Climatic Optimum (MMCO), which resulted in the extension of warm water poleward in the North Pacific (Oleinik et al., 2003) as well as in coastal waters of the South Atlantic in central Argentina (Casadío et al., 2005). This period of warming very likely made it possible for temperate water species to disperse across the tropics and to permit introduction of Tethyan species into areas such as New Zealand.

Post-Miocene.-A total of 35 genera have been recorded from Pliocene or Pleistocene occurrences in the study area, based upon 61 species-level records. All are extant genera. With a single exception, all of the occurrences are in the temperate and tropical latitudes. The sole exception, Linuparus from the Pliocene of Antarctica (Feldmann and Quilty, 1997), is remarkable because very few decapods are known from the circum-Antarctic region today, and there are only two other post-Eocene occurrences of decapods in Antarctica, both from the Miocene. As will be discussed below, Gorny (1999) recently summarized extant decapod occurrences in the high southern latitudes and observed that some benthic and pelagic shrimp, a few benthic king crabs, and one pelagic crab constitute the entire known extant decapod fauna of the Antarctic. None of the groups represented has a robust fossil record. Lithodids, for example, have been recorded in the fossil record only once (Feldmann, 1998).

Temperate latitude sites in New Zealand and South Africa have yielded 27 species-level occurrences arrayed in 19 genera. The remaining 33 species-level occurrences in 18 genera are in the tropical regions of Australia, Peru, and the Caribbean. Thirteen of the genera from the southern temperate latitudes have their sole known fossil record from that region and six genera are known only from the tropical latitudes during this time interval.

A relatively large amount of interchange occurred from one region to another during this time (Fig. 3.1). Four genera, Metanephrops, Lyreidus, Carcinoplax H. Milne Edwards, 1852, and Romaleon Gistl, 1848, are noted in the North Pacific region during this time, having previously been known from the region of Australia and New Zealand. One genus, Macrophthalmus Desmarest, 1823, is first recorded in Australia although it had an earlier fossil record in the North Atlantic. The temperate region of South Africa had additions to its fauna from the Indo-Pacific region in the form of Podophthalmus Lamarck, 1801; Atergatis de Haan, 1833; Charybdis de Haan, 1833; and Myra Leach, 1817. Pilumnus Leach, 1815b and Actaea de Haan, 1833, previously known from either the North Atlantic or Indo-Pacific regions, first appeared in the Central American region during the post-Miocene and Ocypode Weber, 1795 dispersed from the southern temperate

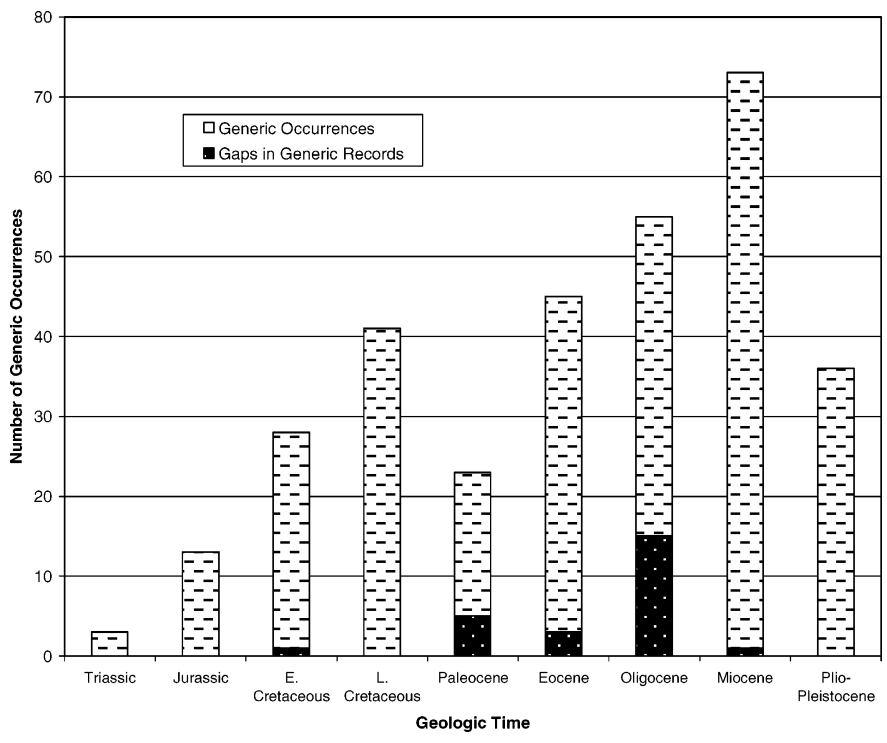

FIGURE 5-Histogram of number of genera known from the study arrayed against time intervals. Data from Table 2.

latitudes of Argentina into the Central American and North Atlantic regions.

\section{DISTRIBUTION, EVOLUTION, AND EXTINCTION PATTERNS}

Assessing the quality of the record.-The quality of interpretations of the distribution patterns is based upon the quality of the database upon which conclusions are drawn. For example, Kauffman (1973) pointed out that the systematic record of the mollusks was fragmented enough that paleobiogeographic syntheses were difficult to perform without reassessment of the faunal record. In the case of paleobiogeographic studies of decapods, although it is thus far not possible to have stratigraphic resolution at a scale fine enough to actually trace routes or determine precise timing of radiation or dispersal, the problem of uniformity of systematic treatment has largely been resolved. With very few exceptions, all of the taxonomic determinations in this study have been verified by one or both of the authors. Many of the included families have been revised recently by the authors in papers cited herein. Thus, it is now possible to determine broad patterns of distribution of lineages, provided enough data are available. In the present study, based upon occurrences of 433 species records in 152 genera, coupled with all known records of the 152 genera in other parts of the world, it is possible to delineate generalized patterns of origin and dispersal. The Southern Hemisphere records represent as comprehensive a survey as is currently possible. Figure 5 illustrates the number of generic occurrences arrayed against geologic time. Added to the records of genera in each of the time intervals are genera that are interpreted as having existed by virtue of their have been recognized in earlier and in subsequent time intervals, the so-called Lazarus Taxa (Jablonski, 1986).

The quality of stratigraphic resolution varies considerably. For example, the stratigraphy of New Zealand has been worked out in detail and, with the exception of very old records of occurrence of decapods, precision of stratigraphic placement can be resolved to the level of stage (Feldmann and Keyes, 1992). In South America, as well as most other parts of the Southern Hemisphere, stratigraphic precision typically constrains ranges to the level of system or series, and problems in correlation arise because not enough stratigraphic work has been done. Determination of age is made more difficult because of the differences in index taxa from the Northern and Southern hemispheres. Thus, if index taxa were 
defined in northern temperate regions, as is often the case, it is difficult to determine precise Southern Hemisphere equivalents. This explains, for example, why the New Zealand standard time scale continues to refer to New Zealand series and stage names. In other areas of the Southern Hemisphere, reference is commonly made to European system and stage names; however, the problems of correlation continue to exist.

Distributional pathways.-The question of distributional pathways in the evolution of Southern Hemisphere faunas has been examined in detail in studies of molluscan paleobiogeography. In the context of interpretation of the decapod record, which is discussed below, several landmark papers on molluscan paleobiogeography have been published in the past 25 years. Zinsmeister (1979) introduced the term "Weddellian Province" to include the southern high latitude continents of Australia, New Zealand, Antarctica, and southern South America that formed a more or less contiguous landmass throughout the Late Cretaceous and early Paleogene. Molluscan faunal interchange throughout the Weddellian Province was high, and the faunal diversity throughout the province was low (Zinsmeister, 1979, 1982). He postulated that the province was a discrete unit until its final fragmentation in the late Eocene and early Oligocene (Zinsmeister, 1979). Crame (1986, 1992, 1993) expanded upon these observations and suggested that global changes in molluscan faunal composition were strongly affected by the history of the high southern latitudes. Crame suggested that the paleobiogeographic patterns in the Late Mesozoic, Paleogene, and early Neogene were largely set by vicariant events as the southern continent fragmented. Faunal diversity in the southern continents increased as endemism increased. Another possible consequence of fragmentation of the southern continents was that it served as one of the mechanisms to explain bipolar and amphitropical distribution of molluscan faunas (Crame, 1993 and references therein). The patterns of decapod distribution, as discussed herein, are largely consistent with those outlined for the mollusks.

As discussed earlier, it is premature to develop area cladograms of decapods in the Southern Hemisphere because the order has not been subjected to a rigorous phylogenetic analysis and the number of occurrences of taxa in the Southern Hemisphere is small, relative to the area. Nonetheless, the systematic placement of taxa within families has been confirmed by us and, although the data are not robust enough to define the complete areas of occurrence, there is sufficient occurrence data to present the generalizations herein.

Examination of the patterns of distribution inferred from the occurrences of decapod genera throughout the Southern Hemisphere (Figs. 1-4; Table 1) confirms that interchange of taxa from one hemisphere to another has been occurring throughout the Mesozoic and Cenozoic. The pathways depicted on the maps (Figs. 1-3) must be understood to have been drawn as the shortest pathways and do not necessarily imply actual routes. It is probable that much of the dispersal occurred along continental shelf areas rather than across broad expanses of open ocean. However, during the Mesozoic and Paleogene, the width of the Atlantic basin was substantially less than it is today. Therefore, larval dispersal across the open Atlantic was much more likely than it is today and was an important dispersal pathway for decapods.

Another important dispersal pathway for decapods through most of the Mesozoic and Cenozoic was the Tethys. Numerous taxa that appear to have originated in Tethyan locations dispersed east and west within the tropics (Schweitzer et al., 2002), and this pattern was certainly enhanced by the narrowness of the Atlantic. From a paleobiogeographic standpoint, it is even more interesting to note that several Southern Hemisphere taxa have moved from one hemisphere to another both by arising in the tropics and dispersing into temperate latitudes or by arising in temperate latitudes in one hemisphere and dispersing into subtropical or temperate latitudes in the other. These patterns are generally referred to as amphitropical. Similar patterns were recognized in the paleobiogeography of decapods from the North Pacific Ocean (Schweitzer, 2001; Schweitzer et al., 2002). The precise mechanisms for this type of pattern in which organisms disperse across regions with significantly different thermal ranges are poorly known. It is possible that the organisms disperse aross the tropics by migrating through deeper, and therefore cooler, settings as discussed by Crame (1992, 1993). Another pattern, that of high latitude origins of decapod taxa, is a long-term pattern that warrants further discussion.

High latitude origins.-The high southern latitudes as a region of origin of new species and dispersal into lower latitudes in the Southern Hemisphere (Feldmann and Zinsmeister, 1984b; Zinsmeister and Feldmann, 1984; Crame, 1987) and into the North Pacific (Schweitzer, 2001) has been well documented. This pattern is much more common than previously thought and occurred either as organisms dispersed northward into deeper water along thermal gradients or as they remained in shallow-water settings and adapted to warmer water conditions. This pathway can be recognized in the Jurassic, Cretaceous, Paleocene, and Eocene. In the Jurassic, of the three genera known from Antarctica, Antarcticheles arose in that region and one other may also have originated there. In the Early Cretaceous, 13 genera are known from the high southern latitudes, of which seven originated there and, of the seven, three dispersed into the Northern Hemisphere. In the Late Cretaceous there were also seven origins of decapod genera in the high southern latitudes. Among the Late Cretaceous genera, four have living congeneric descendants, one was the marine ancestor to a family of living nonmarine decapods, the aeglids (Feldmann, 1984), and two were endemic to the Antarctic. No high latitude origins of decapods have been noted in the $\mathrm{Pa}-$ leocene; however, 10 of 25 genera known from the high southern latitude Paleocene originated there at an earlier time, five in Antarctica and five in New Zealand. Only two of these genera were endemic to the area and, with the exception of these two, all dispersed into other areas subsequent to the Paleocene. Seventeen of the 25 genera known from Eocene high southern latitude occurrences have extant congeneric descendants. Thus, the region has had a substantial influence on the biotic framework of modern decapod faunas.

Subsequent to the Eocene, the development of the circum-Antarctic current system effectively isolated Antarctica from the rest of the world. It is likely that the diversity of decapods decreased in Antarctica because of this isolation. The only post-Eocene occurrences of fossil decapods in Antarctica are two species on King George Island during the Miocene and one in Queen Maud Land during the Pliocene. Thus, following the Eocene, the high southern latitudes apparently ceased to be an important site of origination for decapods.

Until fairly recently, the Antarctic region, south of the Antarctic Convergence, was thought to be largely devoid of benthic decapods and limited in pelagic forms. However, recent studies summarized by Gorny (1999) have recorded several decapod taxa at latitudes as high as $78^{\circ} \mathrm{S}$. The taxa present (Gorny, 1999, table 2) include seven species of shrimp, arrayed in three families, and four species of king crabs, within the Lithodidae, on the continental shelf of Antarctica. In addition, 12 species of pelagic shrimp in three families and one species of grapsid crab, Planes minutus (Linnaeus, 1758), have been collected from pelagic trawls in the circum-Antarctic region (Gorny, 1999). From a paleontological point of view, the array of taxa is interesting because nearly all are representatives of groups that have exceedingly 
sparse fossil records. Shrimp in general tend to be underrepresented in the fossil record because they have weakly calcified cuticle. Although lithodid anomuran crabs may have well-calcified cuticle, they have been recorded in the fossil record only once (Feldmann, 1998), probably because many of them live in outer shelf and slope habitats that are infrequently represented in the fossil record. Although the genus Planes Bowditch, 1825 is known from Oligocene occurrences in the Caucasus (Glaessner, 1969), grapsids in general are rare fossils because most live in habitats that are not conducive to preservation.

Cretaceous/Paleogene extinction event.-The scenario of extinction and subsequent recovery resulting in differences in composition between Late Cretaceous faunas and those of the Paleocene have been recast many times. MacLeod and Keller (1996) provided a summary of several views and an analysis of the effects of the extinction events on different taxa. Some of the problems that make it difficult to determine whether the changes resulted from a short-term catastrophic event or were drawn out over a longer time interval include lack of precise stratigraphic control, lack of exposure of fossiliferous rocks across the Maastrichtian/Danian boundary, and the vagaries of assessing the fossil record. Although a protracted discussion of these problems is not relevant here, certain observations relative to occurrences in the Southern Hemisphere are necessary.

Stratigraphic control remains a problem when looking at occurrences in the Southern Hemisphere. Many of the taxa were collected and described many years ago when stratigraphic resolution was limited. In all probability, that problem will never be completely and satisfactorily resolved because it is difficult or impossible to relocate the type localities and, even then, the probability of finding more specimens is low. However, in one area of the Southern Hemisphere, the question of stratigraphic resolution has been addressed, yielding very important results relative to the K/P extinction event(s). Crame et al. (1996) examined the stratigraphic distribution of disappearances of inoceramid bivalves and belemnites in the James Ross Basin area of the Antarctic Peninsula. They demonstrated disappearance of these taxa over a time span from the Aptian into the Paleocene and demonstrated that, with the exception of a few belemnite taxa, all were extirpated prior to the end of the Maastrichtian and all were gone well before the end of the stage. Although the pattern is suggestive, there are far too few specimens and there is insufficient stratigraphic control of decapod distributions to extend the pattern to decapods.

With regard to exposure of rocks of appropriate age, the problem is particularly acute with Paleocene rocks. As discussed above, Paleocene, and particularly Danian, exposures are limited because that interval is characterized by a period of lowstand of sea level. Following the Paleocene, the Eocene deposits overlapped those of the Paleocene as this was a time of general highstand of sea level. Thus, although there are widespread Maastrichtian marine deposits around the world, the areal extent of marine Paleocene rocks is limited and that, in turn, limits the availability of marine fossils of that age.

Finally, two different problems have traditionally plagued evaluation of faunal change across the Cretaceous/Paleogene boundary. First, compilation of taxonomic lists from the literature invariably must involve acceptance of the systematic judgments of others and, given that some of the work is old, it is not always possible to have full confidence in the identifications, particularly in the absence of good photographic illustrations. The second problem is that, very often, different specialists devote their efforts solely to Cretaceous faunas or to Cenozoic faunas to the exclusion of faunas of other ages. This has led to a kind of "stratigraphic paleontological nomenclature" in which different names are placed on fossils of different ages despite their morphological similarities. We have attempted to reduce the magnitude of these problems by personally examining nearly all the fossils included in this study. The end result has been that the problems in assessment of the faunal changes across the Mesozoic/Cenozoic boundary have been reduced as much as possible. The results and the conclusions are based upon enough taxa that the decapod record can now be considered robust enough to be tested against other, even more robust, taxonomic groups, and to studies of the Cretaceous/Paleogene extinction of decapods known from other regions (Collins and Jakobsen, 1994; Schweitzer, 2001; Schweitzer et al., 2002).

Evaluation of the change in faunas across the K/P boundary is based upon the data in Figure 4 and Tables 1 and 2. A total of 19 genera of decapods are known from both Maastrichtian occurrences in the study area and from Cenozoic occurrences somewhere in the world, 10 of them in the Paleocene of the Southern Hemisphere. Of these 10, two genera are known from the Central American, paleotropical region and eight are found in the extratropical Southern Hemisphere. Twenty-one genera known from Maastrichtian occurrences in the study area do not cross the boundary. This number includes 11 genera represented either by single occurrences or species that are endemic to a relatively small Southern Hemisphere region. The remaining 10 genera are known from the study area as well as sites elsewhere in the world. Thus, about $50 \%$ of the genera in the study area survived the boundary event. This figure is undoubtedly affected strongly by limited collecting in the area, a problem that is less severe when assessing statistics at the family level. In the North Pacific realm, the percentage of generic decapod extinctions was higher: 16 of 26 genera, $62 \%$, became extinct by the end of the Cretaceous (Schweitzer and Feldmann, 2000c, 2001b; Schweitzer, 2001; Schweitzer et al., 2002, 2003). Of the 16 genera that did not survive the Cretaceous, only five, $31 \%$, are known with certainty in the Maastrichtian. Only three families, the Mecochiridae, Prosopidae, and Carcineretidae, became extinct by the end of the Cretaceous. These numbers may be biased by a small sample size relative to that for the Southern Hemisphere. In the Central Americas, about $70 \%$ of the decapod genera became extinct by the end of the Cretaceous; however, $61 \%$ of those genera becoming extinct had done so before the Maastrichtian. Thus, many of the extinctions were not a result of the end-Cretaceous event(s). This, as well as the differing patterns in the three study areas, suggests that the Late Cretaceous extinctions were complex and multicausal.

Statistics regarding the fate of families of decapods permit a somewhat different conclusion. Of the 27 families of decapods known from the Cretaceous of the study area, 23 families survived into the Cenozoic, a total of $85 \%$. Of the four families that suffered extinction in the Cretaceous, only the Mecochiridae had a global distribution in the Cretaceous, and their diversity certainly had declined well before the end of the period (Förster, 1971). The Torynommatidae was endemic to Australia in the Early Cretaceous but, in the Late Cretaceous its distributional pattern becomes diffuse. Eodorippe, known from the Campanian and Maastrichtian of New Zealand, has an earlier occurrence in Japan (Collins et al., 1993), and Binkhorstia Noetling, 1881, which recently has been assigned to the family (Glaessner, 1980; van Bakel et al., 2003), is known from the Maastrichtian of Europe. The generic placements within this family must be reevaluated before decisive paleobiogeographic interpretations can be made. The other two families had limited distribution throughout their history. The Retrorsichelidae were known from a single region in Antarctica from a single genus. The Carcineretidae were limited to several genera endemic to the Central American region. One genus within the family, Carcineretes, is known to occur very close to the Cretaceous/Tertiary boundary and may, indeed, be the only 
decapod taxon clearly suffering extinction as a result of the Chixulub impact (Vega et al., 1997; Feldmann et al., 1998). The overall pattern of survival of families across the Cretaceous/Paleogene boundary in the study area mirrors that previously recognized with decapod faunas elsewhere in the world (Collins and Jakobsen, 1994; Schweitzer, 2001, Schweitzer et al., 2002). In the North Pacific, eight of the nine families, 89\%, known from Cretaceous rocks survived into the Paleocene (Schweitzer, 2001). Of the decapod families known from Cretaceous rocks of the Central Americas, only the Dakoticancridae and Carcineretidae, which were endemic to the region, and the Etyiidae Guinot and Tavares, 2001, became extinct. The remainder of the families, at least 14 and perhaps more, survived into the Paleocene. The decapods, at least at the family level, were not severely affected by the boundary "extinction" event.

\section{SUMMARY AND CONCLUSIONS}

Knowledge of the geological record of fossil decapod crustaceans in the Southern Hemisphere has grown rapidly in the past two decades and has now reached the level where it is possible to attempt a paleobiogeographic synthesis. Verification of nearly every one of the 441 species-level records, in 154 genera, has provided a database that is both internally consistent and that can be readily compared to decapod records that have been similarly verified in the North Pacific and Central American regions.

Decapod crustaceans have been described in rocks in the Southern Hemisphere, ranging in age from Early Triassic to Pleistocene; however, the Triassic occurrences are limited to endemic shrimp taxa in Madagascar that do not presently provide paleobiogeographic information. In the Jurassic a pattern of high latitude origin of decapod taxa is first recognized and this pattern persists into the Eocene. Although some of the taxa that originated in the high southern latitudes remained endemic to that region, numerous of them were progenitors of genera that later appeared in shallow- and deepwater assemblages throughout both hemispheres. At least one genus, Homolodromia, that evolved in the Late Cretaceous of New Zealand, survives today.

The distributional patterns of Southern Hemisphere decapods document a long history of interchange of taxa between the Southern and Northern hemispheres. This pattern is first observed in the Jurassic and is a prominent distributional pattern throughout subsequent time intervals. Although some of this interchange occurs within the tropical and subtropical regions, a significant number of taxa are known from temperate and high latitude occurrences in both hemispheres, the so-called amphitropical and/or bipolar distributions. These distributional occurrences have been interpreted to have been possible by means of passage through the tropical regions along deeper, cooler water pathways. Interchange between hemispheres during the Miocene was enhanced by general amelioration of oceanic temperatures as a result of the MMCO.

Patterns of endemism changed throughout the history of development of Southern Hemisphere decapods. Early history, at least into the Late Cretaceous, was marked by a kind of Gondwanan distribution with similar taxa inhabiting broad regions of the southern continents, including the Weddellian Province. Breakup of the southern continents in the Paleogene resulted in increased endemism so that highly endemic faunas characterize Eocene occurrences, and endemicity remained fairly high thereafter. That pattern was probably strengthened by the onset of the circum-Antarctic circulation pattern that was initiated near the close of the Eocene and has persisted, and generally strengthened, to the present. Development of that circulation pattern also marked a severe decline in the influence of the high southern latitudes on global decapod distributions.
The magnitude of the effect of the Cretaceous/Paleogene extinction event on Southern Hemisphere decapods seems to be of similar magnitude to that documented in Europe, the North $\mathrm{Pa}-$ cific, and Central America. The percentage of genera that do not cross the K/P boundary is about $50 \%$; however, $85 \%$ of families survived the event. Lack of precise stratigraphic resolution in some Southern Hemisphere occurrences obscures detail of the extinction patterns, but it appears that most extinctions in the Cretaceous occurred either in the Campanian or the very early Maastrichtian; only a few taxa can be documented to survive up to the end of the Cretaceous and then become extinct.

Although the precision of the distributional patterns of Southern Hemisphere decapods will undoubtedly be improved with additional discovery and interpretation of faunas, the patterns described herein mark the first attempt at a global-scale synthesis of paleobiogeographic patterns. The magnitude of the database is now great enough to make such a synthesis possible. Subsequent work on the phylogeny of the Decapoda, coupled with additional records of occurrence, will permit more rigorous methods of analyzing the biogeographic patterns. It is hoped that this work will serve as a stimulus for workers to expand our knowledge of the fauna of those regions as well.

\section{ACKNOWLEDGMENTS}

Initial introduction of the senior author to the study of Southern Hemisphere, specifically Antarctic, decapods was made by W. J. Zinsmeister, who supported early field work. His generosity and efforts are greatly appreciated. Field work in Argentina and Chile was conducted in association with M. Aguirre-Urreta, University of Buenos Aires; S. Casadío, University of La Pampa; L. ChirinoGálvez, Valparaiso, Chile; and Miguel Griffin and A. Parras, University of La Pampa. Assistance in preparation of graphical material was provided by D. Waugh, Department of Geology, Kent State University. This work has been supported by National Science Foundation grants OPP 8715945, OPP 8915439, OPP 9417697, OPP 9526252, OPP 9909184, and National Geographic Society Grant 4375 to Feldmann and National Science Foundation grant INT 0003058 and National Geographic Society Grant 6265 98 to Feldmann and Schweitzer. Helpful reviews by F. R. Schram, University of Amsterdam; B. S. Lieberman, University of Kansas; and an anonymous reviewer substantially improved the work. Our thanks to these individuals.

\section{REFERENCES}

AdAms, A., AND A. White. 1848. Crustacea, p. i-viii, 1-66, pls. 1-13. In A. Adams (ed.), The Zoology of the Voyage of H.M.S. Samarang, 1843-1846. London.

Aguirre-Urreta, M. B. 1982. Crustaceos decapodos Barremianos de la region del Tucu-Tucu, Provincia de Santa Cruz. Amegheniana, 14(34):303-317.

Aguirre-Urreta, M. B. 1989. The Cretaceous decapod Crustacea of Argentina and the Antarctic Peninsula. Palaeontology, 32:499-552.

Aguirre-Urreta, M. B. 1990. Nuevos crustaceos decapodos (Brachyura y Anomura) en el Terciario de Patagonia, Argentina. V Congreso Argentino de Paleontologia y Bioestratigrafia, Actas I:149-154.

AguirRe-UrRetA, M. B. 1992. Tertiary freshwater Decapoda (Crustacea: Parastacidae) from the Nirihuau Basin, Patagonia, Argentina. Journal of Paleontology, 66:817-825.

Aguirre-Urreta, M. B., AND V. A. Ramos. 1981. Crustaceos decapodos del Cretacico Inferior de la Cuenca Austral, Provincia de Santa Cruz, Argentina. Cuencas sedimentarias del Jurásico y Cretácico de América del Sur, 2:599-623.

Aguirre-Urreta, M. B., S. Marenssi, and S. Santillana. 1995. A new Eocene crab (Crustacea, Decapoda) from Seymour Island, Antarctica. Antarctic Science, 7(3):277-281.

Aguirre-Urreta, M. B., L. A. Buatois, G. C. B. Chernoglasov, and F. A. Medina. 1990. First Polychelidae (Crustacea, Palinura) from the Jurassic of Antarctica. Antarctic Science, 2(2):157-162. 
Alcock, A. 1899. An account of the deep-sea Brachyura collected by the Royal Indian marine survey ship "Investigator." Trustees of the Indian Museum, Calcutta, 85 p., 4 pls.

Alcock, A. 1900. Materials for a Carcinological fauna of India. No. 6. The Brachyura Catometopa, or Grapsoidea. Journal of the Asiatic Society of Bengal, 69(part 2, no. 3):279-456.

BALL, H. W. 1960. Upper Cretaceous Decapoda and Serpulidae from James Ross Island, Graham Land. Falkland Islands Dependencies Survey Scientific Reports, 24, 30 p.

BeLL, T. 1850. Notes on the Crustacea of the Chalk Formation, p. 344345, pl. 38. In F. Dixon (ed.), The Geology and Fossils of the Tertiary and Cretaceous Formations of Sussex. Longman, Brown, Green, and Longmans, London.

BelL, T. 1858. A monograph of the fossil malacostracous Crustacea of Great Britain, Pt. I, Crustacea of the London Clay. Palaeontographical Society Monograph, London, $44 \mathrm{p}$.

BELL, T. 1863. A monograph of the fossil malacostracous Crustacea of Great Britain, Pt. II, Crustacea of the Gault and Greensand. Palaeontographical Society Monograph, London, 40 p., 11 pls.

BeuRlen, K. 1928. Die Decapoden des schwäbischen Jura mit Ausnahme der aus den oberjurassischen Plattenkalken stammenden. Palaeontographica, 70:115-278, pls. 6-8.

Beurlen, K. 1930. Vergleichende Stammesgeschichte Grundlagen, Methoden, Probleme unter Besonderer Beruchsichtingung der hoheren Krebse. Fortschrifte Geologie und Palaeontologie, 8:317-586.

BeuRlen, K. 1950. Alguns restos de Crustáceos Decápodes d'água doce fósseis no Brasil. Anais da Academia Brasiliera de Ciencias, 22(4): 453-459.

Beurlen, K. 1958a. Contribuição à paleontologia do estado do Para: Crustáceos Decápodos da Formação Pirabas. Boletim do Museu Paraense Emilio Goeldi, nova série, Geologia, 5:1-48, pls. 1-4.

Beurlen, K. 1958b. Dois crustaceos do Cretáceo superior do nordeste do Brasil (Decapoda, Brachyura). Boletim do Museo Nacional, nova série (Rio de Janeiro, Brasil), 26:1-23.

BeuRlen, K. 1962. O género Callianassa nas formações Cretácicas de Pernambuco. Arquivos de Geologia, Universidad do Recife, 2:1-10.

BeURLEN, K. 1965. Crustáceos Decápodos na Formação Riachuelo (Cretáceo-Sergipe). Anais da Academia Brasiliera de Ciencias, 37(2):267272.

Blow, W. C., AND R. B. ManNing. 1996. Preliminary descriptions of 25 new decapod crustaceans from the middle Eocene of the Carolinas, U.S.A. Tulane Studies in Geology and Paleontology, 29:1-26.

BöHM, J. 1911. Callianassa burckhardti n. sp. hebst einer Zusammentstellum der fossilen Arten der Gattung Callianassa. Zeitschrift. Deutsche Geologische Gesellschaft, 63:37-41.

Bosc, L. A. G. 1802. Histoire naturelle des Crustacés, contenant leur description et leurs moeurs, avec figures dessinées d'après nature. De Guilleminet, Paris, 1:1-258, pls. 1-8; 2:1-296, pls. 9-18.

Bowditch, T. E. 1825. Excursions in Madiera and Porto Santo During the Autumn of 1823, while on his Third Voyage to Africa. London, 278 p., 12 pls.

Brito, I. M. 1971. Contribuição ao Conhecimento dos Crostáceos Decápodos da Formação Pirabas. I. Brachyura Brachyryncha. Anais da Academia Brasiliera de Ciencias, 43:489-498.

BRODERIP, W. 1835. Crustacea. Proceedings of the Geological Society of London, 2:201-202.

Carriol, R. P., C. DE Muizon, and S. Secretan. 1987. Les crustacés (Cirripedia et Decapoda) du Néogène de la côte Péruvienne. Annales de Paléontologie (Vert.-Invert.), 73:137-164.

Casadío, S., R. M. Feldmann, And K. A. Foland. 2000. ${ }^{40} \mathrm{Ar} /{ }^{39} \mathrm{Ar}$ age and oxygen isotope temperature of the Centinela Formation, southwestern Argentina: An Eocene age for crustacean-rich "Patagonian" beds. Journal of South American Geology, 13:123-132.

Casadío S., R. M. Feldmann, A. Parras, and C. E. Schweitzer. 2005. Miocene fossil Decapoda (Crustacea: Brachyura) from Patagonia, Argentina and their paleoecological setting. Annals of Carnegie Museum, 74(3).

Casadío, S., G. R. Guerstein, S. Marenssi, S. Santillana, R. FeldMANN, A. PARras, AND C. Montalvo. 2000. Evidencias para una edad oligocena de la Formacíon Centinela, suroeste de Santa Cruz, Argentina. Resúmenes de la Reuníon Annual de Comunicaciones de la APA, Ameghiniana, 37(4):71R.

Casadío, S., A. De Angeli, R. M. Feldmann, A. Garassino, J. L.
Hetler, A. Parras, and C. E. Schweitzer. 2004. New decapod crustaceans (Thalassinidea, Galatheoidea, Brachyura) from the late Oligocene of Patagonia, Argentina. Annals of Carnegie Museum, 73:2547.

Chirino-Gálvez, L. 1993. Cenozoic crabs from Chile. Unpublished M. S. thesis, Kent State University, Kent, Ohio, 280 p.

CHONG, G., AND R. FöRSTER. 1976. Chilenophoberus atacamensis, a new decapod crustacean from the Middle Oxfordian of the Cordillera de Domeyko, northern Chile. Neues Jahrbuch für Geologie und Paläontologie, Monatshefte, 3:145-156.

Collins, J. S. H. 1997. Fossil Homolidae (Crustacea; Decapoda). Bulletin of the Mizunami Fossil Museum, 24:51-71.

Collins, J. S. H., AND S. L. JAKOBSEN. 1994. A synopsis of the biostratigraphic destribution of the crab genera (Crustacea, Decapoda) of the Danian (Palaeocene) of Denmark and Sweden. Bulletin of the Mizunami Fossil Museum, 21:35-46.

Collins, J. S. H., AND S. F. MorRIS. 1975. A new crab Costacopluma concava from the Upper Cretaceous of Nigeria. Palaeontology, 18:823829.

Collins, J. S. H., AND S. F. MorRIs. 1976. Tertiary and Pleistocene crabs from Barbados and Trinidad. Palaeontology, 19:107-131.

Collins, J. S. H., AND S. F. MoRris. 1978. New lower Tertiary crabs from Pakistan. Palaeontology, 21:957-981.

Collins, J. S. H., AND R. W. PORTELL. 1998. Decapod, stomatopod and cirripede Crustacea from the Pliocene Bowden Shell Bed, St Thomas Parish, Jamaica. Contributions to Tertiary and Quaternary Geology, 35(1-4):113-127.

Collins, J. S. H., R. Higgs, AND B. Cortitula. 1994. A new crab, Costacopluma bifida (Crustacea, Decapoda) from the Palaeocene of Venezuela. Bulletin of the Mizunami Fossil Museum, 21:29-34.

Collins, J. S. H., Y. Kanie, AND H. Karasawa. 1993. Late Cretaceous crabs from Japan. Transactions and Proceedings of the Palaeontological Society of Japan, n. s., 172:292-310.

Colosi, G. 1923. Una specie fossile de Gerionide (Decapodi brachiuri). Bolettino della Societá dei Naturalisti in Napoli, 35 (series 2, vol. 15), 37:248-255.

Cooper, M. R., AND B. F. Kensley. 1991. An early Pleistocene decapod crustacean fauna from Zululand. South African Journal of Science, 87: 601-604.

Crame, J. A. 1986. Late Mesozoic bipolar bivalve faunas. Geological Magazine, 123:611-618.

CRAME, J. A. 1987. Late Mesozoic bivalve biogeography of Antarctica, p. 93-102. In G. D. McKenzie (ed.), Gondwana Six: Stratigraphy, Sedimentology, and Paleontology. Geophysical Monograph, 41. American Geophysical Union, Washington, DC.

Crame, J. A. 1992. Evolutionary history of the Polar regions. Historical Biology, 6:37-60.

CRAME, J. A. 1993. Bipolar molluscs and their evolutionary significance. Journal of Biogeography, 20:145-161.

Crame, J. A., S. A. Lomas, D. Pirrie, And A. Luther. 1996. Late Cretaceous extinction patterns in Antarctica. Journal of the Geological Society, London, 153:503-506.

Cresswell, A. W. 1886. Notes on some fossil crabs from the Miocene rocks of Corio Bay. Victorian Naturalist, 3(6):86-91.

Damborenea, S. E., AND M. O. ManceÑIDO. 1987. Primer Glypheidae (Crustacea, Decapoda) de America del Sur en el Toarciano de la provincia de Mendoza, Argentina. Notas del Museo de La Plata, 21, Paleontologia, 106:49-65.

DANA, J. D. 1851a. On the classification of the Crustacea Grapsoidea. American Journal of Science and Arts, 12:283-290.

DANA, J. D. 1851b. On the classification of the Maioid Crustacea or Oxyryncha. American Journal of Science and Arts, (2) 11:425-438.

DANA, J. D. 1852. Crustacea. In United States exploring expedition during the years 1838,1839,1840,1841, 1842 under the command of Charles Wilkes, Part I, 13:1-685.

DARwIN, C. 1842-1846. Geological Observations on Coral Reefs, Volcanic Islands, and on South America: Being the Geology of the Voyage of the Beagle, under the Command of Capt. FitzRoy, during the Years 1832-1836. Smith, Elder, London.

DE HaAn, W. 1833-1850. Crustacea, p. 1-243, pls. a-j, 1-q, 1-55. In P. F. von Siebold, Fauna Japonica sive Descriptio Animalium, quae in Itinere per Japoniam, Jussu et Auspiciis Superiorum, qui Summum in India Batava Imperium Tenent, Suscepto, Annis 1823-1830 Collegit, 
Notis, Observationibus et Adumbrationibus Illustravit. Lugduni-Batavorum, Leiden.

Dell, R. K. 1969. A new Pliocene crab of the genus (Trichopeltarion) from New Zealand. Records of the Canterbury Museum, 8:367-371.

DE Saint Laurent, M. 1973. Sur la systématique et la phylogénie des Thalassinidea: Définition des familles des Callianassidae et des Upogebiidae et diagnose de cinq genres nouveaux (Crustacea Decapoda). Comptes Rendus Hebdomadaires des Séances de l'Académie des Sciences, Paris (series D), 277:513-516.

Desmarest, A. G. 1823. Malacostracés: Dictionnaire des sciences naturelles. Vol. 28. F. G. Levrault, Paris, France, p. 138-425.

D'ORBIGNY, A. 1842. Voyage dans l'Amérique méridional, 1826-1833 (III). Géologie et Paléontologie. Pitois-Levrault, Paris, 561 p.

ETHERIDGe, R. 1914. The genus Enoploclytia in the Cretaceous rocks of Queensland. Records of the Australian Museum, 10:271-273.

Etheridge, R. A. 1917. Descriptions of some Queensland Palaeozoic and Mesozoic fossils. 1) Queensland Lower Cretaceous Crustacea. Publications of the Geologic Survey of Queensland, 260, p. 7-10.

Fabricius, J. C. 1793. Entomologia Systematica Emendata et Aucta Secumdum Classes, Ordines, Genera, Species adjectis Synonymis, Locis, Observationibus, Descriptionibus. C. G. Proft et Storch, Hafniae (=Copenhagen), $519 \mathrm{p}$.

FABRICIUS, J. C. 1798. Supplementum Entomologiae Systematicae. C. G. Proft et Storch, Hafniae, (=Copenhagen), 572 p.

Feldmann, R. M. 1984. Haumuriaegla glaessneri n. gen. and sp. (Decapoda; Anomura; Aeglidae) from Haumurian (Late Cretaceous) rocks near Cheviot, New Zealand. New Zealand Journal of Geology and Geophysics, 27:379-385.

Feldmann, R. M. 1989. Metamephrops jenkinsi n. sp. (Decapoda: Nephropidae) from the Cretaceous and Paleocene of Seymour Island, Antarctica. Journal of Paleontology, 63:64-69.

Feldmann, R. M. 1992. The genus Lyreidus de Haan, 1839 (Crustacea, Decapoda, Raninidae): Systematics and biogeography. Journal of $\mathrm{Pa}-$ leontology, 66:943-957.

FelDMANN, R. M. 1993. Additions to the fossil decapod crustacean fauna of New Zealand. New Zealand Journal of Geology and Geophysics, 36:201-211.

Feldmann, R. M. 1994. Antarctomithrax thomsoni, a new genus and species of crab (Brachyura; Majidae) from the La Meseta Formation (Eocene) of Seymour Island, Antarctica. Journal of Paleontology, 68: 174-176.

Feldmann, R. M. 1998. Paralomis debodeorum, a new species of decapod crustacean from the Miocene of New Zealand: First notice of the Lithodidae in the fossil record. New Zealand Journal of Geology and Geophysics, 41:35-38.

FeldMANN, R. M., AND R. K. BEARLin. 1988. Linuparus korura n. sp. (Decapoda: Palinura) from the Bortonian (Eocene) of New Zealand. Journal of Paleontology, 62:245-250.

Feldmann, R. M., AND J. A. CRAmE. 1998. The significance of a new nephropid lobster from the Miocene of Antarctica. Palaeontology, 41: 807-814.

Feldmann, R. M., And R. E. Fordyce. 1996. A new cancrid crab from New Zealand. New Zealand Journal of Geology and Geophysics, 39: 509-513.

Feldmann, R. M., AND A. GAźDZicKI. 1997. A new species of Glyphea (Decapoda: Palinura) from the La Meseta Formation (Eocene) of Seymour Island, Antarctica. Acta Palaeontologica Polonica, 42:437-445.

Feldmann, R. M., AND I. W. Keyes. 1992. Systematic and stratigraphic review with catalogue and locality index of the Mesozoic and Cenozic decapod Crustacea of New Zealand. New Zealand Geological Survey Record, 45, $73 \mathrm{p}$.

Feldmann, R. M., AND R. G. Martins-Neto. 1995. Costacopluma nordestina n. sp. (Decapoda: Retroplumidae) from the Maria Farinha Formation (Paleocene) of Brazil. Journal of Paleontology, 69:610-611.

Feldmann, R. M., AND P. A. Maxwell. 1990. Late Eocene decapod Crustacea from north Westland, South Island, New Zealand. Journal of Paleontology, 64:779-797.

Feldmann, R. M., AND P. A. MAXwell. 1999. A new species of glypheid lobster, Glyphea christeyi (Decapoda, Palinura), from the Eocene (Bortonian) Waihao Greensand, South Canterbury, New Zealand. New Zealand Journal of Geology and Geophysics, 42:75-78.

Feldmann, R. M., And M. Pole. 1994. A new species of Paranephrops White, 1842: A fossil freshwater crayfish (Decapoda: Parastacidae) from the Minuherikia Group (Miocene), Central Otaga, New Zealand. New Zealand Journal of Geology and Geophysics, 37:163-167.

Feldmann, R. M., AND P. G. Quilty. 1997. First Pliocene decapod crustacean (Malacostraca: Palinuridae) from the Antarctic. Antarctic Science, 9:56-60.

Feldmann, R. M., And M. DE SAint Laurent. 2002. Glyphea foresti n. sp. (Decapoda) from the Cenomanian of Northern Territory, Australia. Crustaceana, 75:359-373.

Feldmann, R. M., AND C. E. Schweitzer. 2004. Decapod crustaceans from the early Miocene of northwesternVenezuela (Cerro La Cruz, Castillo Formation). Special Papers in Palaeontology, 71:7-22.

Feldmann, R. M., AND T. Villamil. 2002. A new carcineretid crab (upper Turonian, Cretaceous) of Colombia. Journal of Paleontology, 76:718-724.

Feldmann, R. M., AND M. T. Wilson. 1988. Eocene decapod crustaceans from Antarctica, p. 465-488. In R. M. Feldmann and M. O. Woodburne (eds.), Geology and Paleontology of Seymour Island, Antarctic Peninsula. Geological Society of America Memoir, 169.

Feldmann, R. M., AND W. J. Zinsmeister. 1984a. First occurrence of fossil decapod crustaceans (Callianassidae) from the McMurdo Sound region, Antarctica. Journal of Paleontology, 58:1041-1045.

FeldMANN, R. M., AND W. J. Zinsmeister. 1984b. New fossil crabs (Decapoda: Brachyura) from the La Meseta Formation (Eocene) of Antarctica: Paleogeographic and biogeographic implications. Journal of Paleontology, 58:1046-1061

Feldmann, R. M., C. E. Schweitzer, And A. Encinas. 2005. New decapods from the Navidad Formation (Miocene) of Chile. Journal of Crustacean Biology, 25:427-449.

Feldmann, R. M., C. E. Schweitzer, And S. Marenssi. 2003. Stratigraphy and paleoecology of decapod crustaceans from the La Meseta Formation, Seymour Island, Antarctica. Journal of Geology, 160:151160.

Feldmann, R. M., D. M. Tshudy, And M. R. A. Thomson. 1993. Late Cretaceous and Paleocene decapod crustaceans from James Ross Basin, Antarctic Peninsula. Paleontological Society Memoir, 28, 41 p.

Feldmann, R. M., F. J. Vega, AND T. Villamil. 1998. Cretaceous extinction of the Tethyan crab family Carcineretidae: A victim of the impact? Geological Society of America, Abstracts with Program, 30(7): A-286.

Feldmann, R. M., T. Villamil, And E. G. Kauffman. 1999. Decapod and stomatopod crustaceans from mass mortality Lagerstatten: Turonian (Cretaceous) of Colombia. Journal of Paleontology, 73:91-101.

Feldmann, R. M., M. Aguirre-Urreta, L. Chirino-Gálvez, and S. CASADío. 1997. Paleobiogeography of Cretaceous and Tertiary decapod crustaceans from southern South America: The link with Antarctica, p. 1007-1016. In The Antarctic Region: Geological Evolution and Processes. Terra-Antarctica Publications, Siena, Italy.

Feldmann, R. M., S. Casadío, L. Chirino-Galvéz, and M. AguirreURRETA. 1995. Fossil decapod crustaceans from the Jagüel and Roca Formations (Maastrichtian-Danian) of the Neuquén Basin, Argentina. Paleontological Society Memoir, 43, 22 p.

Feldmann, R. M., M. Fernanda Rodriguez, G. A. Martinez, and M. Aguirre-Urreta. 1997. Costacopluma salamanca new species (Decapoda, Retroplumidae) from the Salamanca Formation (Danian) of Patagonia, Argentina. Journal of Paleontology, 71:125-130.

Feldmann, R. M., L. Chirino-Galvez, G. L. Mason, J. L. Anderson, P. W. Duncan, R. A. Ward, and D. R. Salem. 1993. Fossil Penaeidae (Crustacea: Decapoda) from the Loyola Formation, Ecuador. Annals of Carnegie Museum, 62:229-243.

Filhol, H. 1885. Considerations relatives a la faune des Crustaces de la Nouvelle Zélande. Bibliotheque de l'école des hautes Études, Paris Section des Sciences Naturelles, 30(2):1-60.

Fleming, C. A. 1981. A new grapsid crab from the upper Miocene of New Zealand. Journal of the Royal Society of New Zealand, 11:103108.

FORSKÅL, P. 1775. Descriptiones Animalium, Avium, Amphibiorum, Piscium, Insectorum, Vermium. Ex Officina Mölleri, Aulae Typographi, Hafniae (=Copenhagen), $19+$ xxxii +164 p.

FÖRSTER, R. 1968. Paranecrocarcinus libanoticus n. sp. (Decapoda) und die Entwicklung der Calappidae in der Kreide. Mitteilungen Bayrischen Staatssammlung Paläontologische historische Geologie, 8:167-195. 
FÖRSTER, R. 1970. Neue Dekapoden-Reste aus der Oberkreide von Moçambique, Norddeutschland und den bayerischen Alpen. Paläontologosche Zeitschrifte, 44:134-144.

FÖRSTER, R. 1971. The Mecochiridae, a specialized family of the Mesozoic Glypheoidea (Crustacea, Decapoda). Neues Jahrbuch für Paläontologie, Abhandlungen, 137:396-421.

Förster, R., AND A. vON HillebrandT. 1984. Das Kimmeridge des Profeta-Jura in Nordchile mit einer Mecochirus-Favreina-Vergesellschaftung (Crustacea, Decapoda-Ichnogenus). Mitteilungen Bayrischen Staatssammlung Paläontologische historische Geologie, 24:67-84.

Förster, R., AND W. Stinnesbeck. 1987. Zwei neue Krebse, Callianassa saetosa n. sp. und Homolopsis chilensis n. sp. (Crustacea, Decapoda) aus der Ovber Kreide Zentral-Chiles. Mitteilungen Bayrischen Staatssammlung Paläontologische historische Geologie, 27:51-94.

FÖRSTER, R., A. GAŹDZICKI, AND R. WRONA. 1985. First record of a homolodromiid crab from a Lower Miocene glacio-marine sequence of West Antarctica. Neues Jahrbuch für Geologie und Palaontologie Monatshefte, 6:340-348.

FRITSCH, A., AND J. KAFKA. 1887. Die Crustaceen der böhmischen Kreideformation. Selbstverlag in commission with Fr. Rivnáč, Prag, 53 p., 10 pls.

Gaetani, M., A. Nicora, I. Permoli Silva, E. Fois, E. Garzanti, and A. TINTORI. 1983. Upper Cretaceous and Paleocene in Zanskar Range (NW Himalaya). Rivista Italiana di Paleontologia i Stratigrafia, 89:81118

Garassino, A., And G. Pasini. 2002. Studies on Permo-Trias of Madagascar. 5. Ambilobeia karojoi n. gen., n. sp. (Crustacea, Decapoda) from the Lower Triassic (Olenekian) of Ambilobé region (NW Madagascar). Atti Societa Italiana di Scienze Naturali. Museo Civico di Storia Naturale di Milano, 143/2002(I):95-104.

Garassino, A., AND G. Teruzzi. 1995. Studies on Permo-Trias of Madagascar. 3. The decapod crustaceans of the Ambilobè region (NW Madagascar). Atti Societa Italiana di Scienze Naturali. Museo Civico di Storia Naturale di Milano, 134/1995(I):85-113.

Germar, E. F. 1827. Über die Versteinerungen von Solenhofen. Keferstein's Teutschland geognostisch-geologisch dargestellt, 4(2):89-110, pl. 1.

GILL, T. 1894. A new Bassalian type of crabs. American Naturalist, 28: $1043-1045$

GisTL, J. 1848. Naturgeschichte des Thierreichs für höhere Schulen. Hoffman'scherlags-Buchhandlung, Stuttgart, 220 p., pls. 1-32.

GlAEsSNER, M. F. 1932. Neue Krebsreste aus der Kreide. Jahrbuch der Preussischen Geologischen Landesaanstalt, 53:577-586, pl. 28.

GlaESSNER, M. F. 1933. New Tertiary crabs in the collection of the British Museum. Annals and Magazine of Natural History (tenth series), 27:13-29.

GlaEssner, M. F. 1948. Decapod Crustacea (Callianassidae) from the Eocene of Victoria. Proceedings of the Royal Society of Victoria, $n$. S., 59:1-7.

Glaessner, M. F. 1956. Crustacea from the Cretaceous and Eocene of Western Australia. Journal of the Royal Society of Western Australia, 40:33-35, $1 \mathrm{pl}$.

Glaessner, M. F. 1960. The fossil decapod Crustacea of New Zealand and the evolution of the order Decapoda. New Zealand Geological Survey, Paleontological Bulletin, 31:1-63, pls. 1-7.

Glaessner, M. F. 1969. Decapoda, p. R400-R533, R626-628. In R. C. Moore (ed.), Treatise on Invertebrate Paleontology. Pt. R4(2). Geological Society of America and University of Kansas Press, Lawrence.

GlaEssner, M. F. 1980. New Cretaceous and Tertiary crabs (Crustacea: Brachyura) from Australia and New Zealand. Transactions of the Royal Society of South Australia, 104:171-192.

Glaessner, M. F., AND V. R. RaO. 1960. A new species of crab from the early Tertiary Fuller's Earth deposits of Kapurdi, Rajasthan, western India. Records of the Geological Survey of India, 86:675-682.

GoRnY, M. 1999. On the biogeograhy and ecology of the Southern Ocean decapod fauna. Scientia Marina, 63:367-382.

GRAY, J. E. 1872. Notice of a new Netted Sponge (Meyerella) from the Philippines. Annals and Magazine of Natural History, (4)10:76

GRIFFIN, D. J. G. 1963. Notomithrax gen. nov. and the status of the genus Paramithrax H. Milne Edwards (Crustacea, Brachyura, Majidae). Transactions of the Royal Society of New Zealand, Zoology, 3:229237.
Guinot, D. 1991. Éstablissement de la famille des Poupiniidae pour Poupinia hirsuta gen. nov., sp. nov. de Polynésie (Crustacea Decapoda Brachyura Homoloidea). Bulletin national d'Histoire naturelle, Paris, série 4, 12:577-605.

Guinot, D., AND B. Richer DE Forges. 1980. Crabes de profondeur, nouveaux ou rares, de l'indo-Pacifique (Crustacea, Decapoda, Brachyura) (première partie). Bulletin du Museum national d'Histoire naturelle, Paris, 4th série, 2, section A, no. 4:1113-1153.

Guinot, D., AND B. Richer DE Forges. 1995. Crustacea Decapoda Brachyura: Révision de la famille des Homolidae de Haan, 1839. In A. Crosnier (ed.), Résultats des campagnes MUSORSTOM. Vol. 13. Mémoires du Muséum national d'Histoire naturelle, Paris, 163:283517.

Guinot, D., And M. TAvares. 2001. Une nouvelle famille de Crabes du Crétacé, et al notion de Podotremata Guinot, 1977 (Crustacea, Decapoda, Brachyura). Zoosystema, 23:507-546.

HARBOURT, E. 1905. Die Fauna der Schaumburg-Lippesden Kreidemulde. Abhandlungen Preussische Geologische Landesanst, n. f., 14:1022.

Haswell, W. A. 1882. Catalogue of the Australian stalk- and sessileeyed Crustacea. The Australian Museum, F. W. White, Printer, Sydney, 324 p. + addenda et corrigenda, pls. I-IV.

HeLleR, C. 1865. Reise der osterreichischen Fregatte "Novara" um die Erde in den Jahren 1857-1859 unter den Befehlen des Commodors B von Wullerstorf-Urbair. Die Crustaceen, 1. Vienna.

HERBST, J. F. W. 1782-1804. Versuch einer Naturgeschichte der Krabben und Krebse nebst einer systematischen Beschreibung ihrer verschiedenen Arten. Bey Jon Caspar Fuessly, Zurich, vol. 1 (1782-1790), p. 1-274, text-fig. a, pls. 1-21; vol. 2(1791-1796), p. 1-225, pls. 22-46; vol. 3 (1799-1804), p. 1-66, pls. 47-50.

HoušA, V. 1957 [1956]. Bechleja inopinata n.g., n.sp., ein neuer Krebs aus dem böhmischen Tertiär (Decapoda, Palaemonidae). Ustř̌edního Ústavu Geologického, Sborník (Oddíl Paleontologický), 23:365-377.

HuXLEY, T. H. 1879 [1878]. On the classification and the distribution of the crayfishes. Proceedings of the Scientific Meetings of the Zoological Society of London, 1878:752-788.

Hyden, F. M., AND J. FoRest. 1980. An in situ hermit crab from the early Miocene of southern New Zealand. Palaeontology, 23:471-474.

JABLONSKI, D. 1986. Causes and consequences of mass extinctions; a comparative approach, p. 183-229. In D. K. Elliott (ed.), Dynamics of Extinction. John Wiley and Sons, New York.

JaCQUiNOT, H., AND H. LuCAS. 1853. Voyage au Pole Sud et dans l'Oceanie sur les Corvettes Astrolabe et la Zelee. Zoologie 3, Crustaces. Gide et Baudry, Paris, 107 p.

JENKINs, R. J. F. 1972a. Metanephrops, a new genus of late Pliocene to Recent lobsters (Decapoda, Nephropidae). Crustaceana, 22:161-177.

JENKINs, R. J. F. 1972b. Australian fossil decapod Crustacea: Faunal and environmental changes. Unpublished Ph.D. dissertation, University of Adelaide, Australia, 392 p., 9 tables, 63 figs., 23 pls.

Jenkins, R. J. F. 1974. A new spider-crab from the Miocene of New Zealand. Palaeontology, 17:869-877.

Jenkins, R. J. F. 1977. A new fossil homolid crab (Decapoda, Brachyura), Middle Tertiary, southeastern Australia. Transactions of the Royal Society of South Australia, 101:1-10.

JENKINS, R. J. F. 1985. Fossil spider crabs from Australia. South Australia Department Mines and Energy Special Publication, 5:145-165.

KARASAWA, H. 1993. Cenozoic decapod Crustacea from southwest Japan. Bulletin of the Mizunami Fossil Museum, 20:1-92, 24 pls.

Karasawa, H., AND C. E. Schweitzer. 2004. Revision of the genus Glyphithyreus Reuss, 1859 (Crustacea, Decapoda, Brachyura, Xanthoidea) and recognition of a new genus. Paleontological Research, 8: $143-154$.

Kauffman, E. G. 1973. Cretaceous Bivalvia, p. 353-383. In A. Hallam (ed.), Atlas of Palaeobiogeography. Elsevier, Amsterdam.

KensLey, B. 1985. The faunal deposits of a late Pleistocene raised beach at Milnerton, Cape Province, South Africa. Annals of the South African Museum, 95:111-122.

KishinouYe, K. 1926. Two rare and remarkable forms of macrurous Crustacea from Japan. Annotationes Zoologicae Japonenses, 11:63-70.

Kitchin, F. L. 1908. The invertebrate fauna and palaeontological relations of the Uitenhage Series. Annals of the South African Museum, 7:212268.

LAMARCK, J. B. P. A. DE. 1801. Systême des animaux sans vertèbres, ou 
tableau général des classes, des ordres et des genres de ces animaux; présentant leurs caractères essentials et leur distribution, d'après la considération de leurs rapports naturels et de leur organisation, et suivant l'arrangement établi dans les galeries du Muséum d'Histoire Naturelle, parmi leurs dépouilles conservées: Précédé du discours d'ouverture du cours de zoologie, donné dans le Muséum national d'Histoire naturelle, l'an 8 de la Republique. Déterville, Paris, 438 p.

LAMARCK, J. B. P. A. DE. 1818. Histoire naturelle des animaux sans vetrebres. Vol. 5. Déterville, Paris, 612 p.

LATREILLE, P. A. 1802-1803. Histoire naturelle, générale et particulière, des crustacés et des insects. Vol. 3. F. Dufart, Paris.

LAtreille, P. A. 1806. Genera crustaceorum et insectorum secundum ordinem naturalem in familias disposita, iconibur exemplisque plurimis explicata. A. Koenig, Paris, 302 p.

Latreille, P. A. 1817. Les crustacés, les arachnides et les insectes, p. xxix $+1-653$. In G. Cuvier (ed.), Le règne animal distribué d'après son organization, pour servir de base à l'histoire naturelle des animaux et d'introduction à l'anatomie comparée, editions 1, 3. Déterville, Paris.

Latreille, P. A. 1825. Encyclopédie Méthodique. Histoire Naturelle. Entomologie, ou Histoire naturelle des Crustacés, des Arachnides et des Insectes. Roret, Paris, vol. 10, pt. 1, 344 p.

Latreille, P. A. 1831. Cours d'entomologie: Ou, De l'Histoire naturelle des crustacés, des arachnides, des myriapodes et des insectes; à l'usage des èléves de l'ecole du Muséum d'histoire naturelle; par m. Latreille. Roret, Paris, 568 p., 24 pls.

LEACH, W. E. 1815a. A tabular view of the external characters of four classes of animals, which Linné arranged under Insecta: With the distribution of the genera composing three of these classes into orders, and descriptions of several new genera and species. Transactions of the Linnaean Society of London, 11:306-400.

LeACH, W. E. 1815b. The Zoological Miscellany: Being Descriptions of New, or Interesting, Animals. E. Nodder and Son, London, 2, 154 p., pls. $61-120$.

LEACH, W. E. 1817. The Zoological Miscellany, Being Descriptions of New or Interesting Animals. E. Nodder and Son, London, 3, vi + 151 p., pls. 121-149.

LEACH, W. E. 1820. Galatéadées. Dictionnaire des Sciences Naturelles. F. G. Levreault, Paris, 18:49-56.

LeEne, J. E. 1938. The Portunidae of the Siboga-Expedition. Pt. 1. E. J. Brill, Leiden, $156 \mathrm{p}$.

Lieberman, B. S. 2002. Phylogenetic biogeography with and without the fossil record: Gauging the effects of extinction and paleontological incompleteness. Palaeogeography, Palaeoclimatology, Palaeoecology, 178:39-52.

LinNAEUS, C. 1758. Systema naturae per regna tria naturae, secundum classes, ordines, genera, species, cum characteribus, differentiis, synonymis, locis (tenth edition). I. Laurentii Salvii, Homiae, 824 p.

LőREnthey, E., AND K. BeuRlen. 1929. Die fossilen Decapoden der Länder der Ungarischen Krone. Geologica Hungarica, serie paleontologica, fasciculus 3, 421 p., 12 tabs., 16 pls.

MacLEAY, W. S. 1838. On the brachyurous decapod Crustacea brought from the Cape by Dr. Smith, p. 53-71, pls. 1, 2. In Illustrations of the Annulosa of South Africa; being a portion of the objects of Natural History chiefly collected during an expedition into the interior of South Africa, under the direction of Dr. Andrew Smith, in the years 1834, 1835, and 1836; fitted out by "The Cape of Good Hope Association for Exploring Central Africa." Smith, Elder, London.

MacLeOD, N., AND G. Keller. 1996. Cretaceous-Tertiary Mass Extinctions: Biotic and Environmental Changes. W. W. Norton, New York, $575 \mathrm{p}$.

MANNING, R. B., AND D. L. Felder. 1991. Revision of the American Callianassidae (Crustacea: Decapoda: Thalassinoidea). Proceedings of the Biological Society of Washington, 104:764-792.

ManNing, R. B., AND L. B. Holthuis. 1989. Two new genera and nine new species of geryonid crabs (Crustacea, Decapoda, Geryonidae). Proceedings of the Biological Society of Washington, 102:50-77.

Mantell, G. A. 1833. The Geology of the South-East England. Longman, Rees, Orme, Brown, Green and Longman, London, 435 p.

Martins-Neto, R. G. 1987. Primeiro registro de decápode na Formação Santana, bacia do Araripe (Cretáceo Inferior), Brasil. Ciéncia e Cultura, 39(4):406-410.

Martins-Neto, R. G. 2001. Review of some Crustacea (Isopoda and
Decapoda) from Brazilian deposits (Paleozoic, Mesozoic and Cenozoic) with descriptions of new taxa. Acta Geologica Leopoldensia, XXIV(52/53):237-254

Martins-Neto, R. G., AND S. MezZalira. 1991a. Descrição de novos crustáceos (Caridea) da Formação Santana, Cretáceo Inferior do Nordeste do Brasil. Anais Academia Brasileira de Ciencias, 63(2):155-160.

Martins-Neto, R. G., And S. Mezzalira. 1991b. Revisão dos Palemonídeos Terciários Brasileiros (Crustacea, Caridea) com descrição de novos taxa. Anais Academia Brasileira de Ciencias, 63(4):361-367.

Maury, C. J. 1930. O Cretaceo da Parahyba do Norte. Monographia N. VIII, Ministerio da Agricultura, Industria e Commercio, Serviço Geologico e Mineralogico do Brasil, 305 p.

McCoy, F. 1849. On the classification of some British fossil Crustacea with notices of new forms in the University Collection at Cambridge. Annals and Magazine of Natural History, series 2, 4:161-179, 330335.

McLay, C. L., R. M. Feldmann, and D. A. McKinnon. 1995. New species of Miocene spider crabs from New Zealand, and a partial cladistic analysis of the genus Leptomithrax Miers, 1876 (Brachyura: Majidae). New Zealand Journal of Geology and Geophysics, 38:299-313.

Mertin, H. 1941. Decapode Krebse aus dem subhercynen und Braunschweiger Emscher und Untersenon. Nova Acta Leopoldina, 10:149264, pls. 1-8.

Miers, E. J. 1876. Catalogue of the Stalk- and Sessile-Eyed Crustacea of New Zealand. Janson, London, i-xii, 36 p., pls. 1-3.

Miers, E. J. 1886. Report of the Brachyura collected by H. M. S. Challenger during the years 1873-1876, p. 1-362. In C. W. Thomson and J. Murray (eds.), Report of the Scientific Results of the Voyage of $\mathrm{H}$. M. S. Challenger during the years 1873-1876, Zoology. Johnson Reprints, New York.

MiLNE EdwARDS, A. 1862-1865. Monographie des crustacés de la famille cancériens. Annals des Sciences Naturelles, Zoologie, serie 4 18(1862):31-85, pls. 1-10; 20(1863):273-324, pls. 5-12; series 5, 1(1864):31-88, pls. $1-10 ; 3(1865): 297-351$, pls. 5-13.

Milne Edwards, A. 1873. Descriptions des quelques crustacés nouveaux ou peu connus provenant du Musée de M. C. Godeffrey. Journal of the Museum Godeffroy, 1:77-88.

Milne EdwardS, A. 1873-1881. Étude sur les Xiphosures et les Crustacés de la Région Mexicaine, p. 1-368, pls. 1-61. In Mission Scientifique au Mexique et dans l'Amerique Centrale. Pt. 5. Imprimerie nationale, Paris.

MiLne Edwards, A. 1880. Reports of the results of dredging, under the supervision of Alexander Agassiz, in the Gulf of Mexico and the Caribbean Sea, 1877, '78, '79, by the United States Coast Survey Steamer "Blake"... VII. Etudes préliminaires sur les Crustacés. Bulletin of the Museum of Comparative Zoology at Harvard College, 8:1-68.

Milne Edwards, H. 1832. Observations sur les Crustacés du genre Mithrax. Magazine Zoologique, classe 7, Crustacés, pls. 1-5.

MiLne Edwards, H. 1834-1840. Histoire naturelle des Crustacés, comprenant l'anotomie, la physiologie, et la classification de ces animaux. Vol. 1(1834), 468p.; Vol. 2 (1837), 532 p.; Vol. 3 (1840), 638 p.; Atlas, 32 p., pls. 1-42.

MiLne Edwards, H. 1852. De la famille des ocypodides (Ocypodidae). Second Mémoire, p. 128-166, pls. 3, 4. In Observations sur les affinités zoologiques et la classification naturelle des Crustacés. Annales des Sciences Naturelles (Zoologie), 18.

MiLne Edwards, H. 1853. Mémoire sur la famille des Ocypodiens. Suite (1). Annales des Sciences Naturelles (Zoologie), 20:163-228.

MorRIs, S. F. 1993. The fossil arthropods of Jamaica, p. 115-124. In R. M. Wright and E. Robinson (eds.), Biostratigraphy of Jamaica. Geological Society of America Memoir, 182.

NoETLING, F. 1881. Ueber einige Brachyuren aus dem Senon von Maestricht und dem Tertiär Norddeutschlands. Zeitschrift. Deutsche Geologische Gesellschaft, 33:357-371, pl. 20.

NoETLING, F. 1897. Fauna of the Upper Cretaceous (Maëstrichtien) beds of the Mari Hills. Memoirs of the Geological Survey of India, Palaeontologica Indica, series XVI, 1(3):1-79, pls. 1-23.

Oleinik, A. E., K. B. Barinov, and L. Marinkovich. 2003. Middle Miocene warming at high latitudes: Biogeographic consequences and istopic signatures. Geological Society of America Abstracts with Programs, 35(6):255 
Ortmann, A. 1892. Die Abtheilungen Hippidea, Dromiidea und Oxystomata: Die Decapoden-Krebse des Strassburger Museums, mit besonderer Berücksichtigung der von Herrn Dr. Döderlein bei Japan und bei den Liu-Kiu-Inseln gesammelten und z.Z. im Strassburger Museum aufbewahrten Formen. V. Theil. Zoologische Jahrbücher, Abtheilung für Systematik, Geographie und Biologie der Thiere, 6:532-588, pl. 26.

ORTMAnN, A. 1893. Die Dekapoden-Krebse des Strassburger Museums. 7. Theil. Abtheilung: Brachyura (Brachyura genuina Boas) 2. Unterabtheilung: Cancroidea, 2. Section: Cancrinea, 1. Gruppe: Cyclometopa. Zoologischen Jahrbücher, Abtheilung für Systematik, Geographie und Biologie der Thiere, 7:411-495.

PARKER, T. J. 1883. On the structure of the head in Palinurus with special reference to the classification of the genus. Nature, 29:189-190, $1 \mathrm{pl}$.

PhILIPPI, R. A. 1887. Los fósiles terciarios I cuartarios de Chile. Brockhaus, Leipzig (German version) and Santiago de Chile (Spanish version), 256 p., $56 \mathrm{pls}$.

Powell, A. W. B. 1949. New species of Crustacea from New Zealand of the genera Scyllarus and Ctenocheles, with notes on Lyreidus fastigatus. Records of the Auckland Institute Museum, 3:368-371, 1 pl.

PRASAD, K. N. 1966. Crustacea from the Fuller's Earth deposits of Kapurdi, Rajasthan. Records of the Geological Survey of India, 94:313316.

QuEnstedT, F. A. 1856-1858. Der Jura. Laupp und Eichert, Tübingen, Germany.

RAFINESQUE, C. S. 1815. Analyse de la nature, ou tableau de l'Universe et des corps organisée. J. Baravecchia, Palermo, Italy, 224 p.

Rathbun, M. J. 1892. Catalogue of the crabs of the family Periceridae in the U.S. National Museum. Proceedings of the United States National Museum, 15:231-277, pls. 28-40.

RAthBun, M. J. 1898a. The Brachyura collected by the U.S. Fish Commission Steamer Albatross on the voyage from Norfolk, Virginia to San Francisco, California, 1887-1888. Proceedings of the United States National Museum, 21:567-616.

Rathbun, M. J. 1898b. The Brachyura of the Florida Keys and the Bahamas in 1893. Bulletin from the Laboratories of Natural History of the State University of Iowa, 4(3):349-375.

RAthBun, M. J. 1900 [1902]. Miss Rathbun's description of Zanthopsis cretacea, p. 43-44, pl. 5. In J. C. Branner (ed.), Geology of the Northeast Coast of Brazil. Bulletin of the Geological Society of America, 13.

Rathbun, M. J. 1908. Descriptions of fossil crabs from California. Proceedings of the United States National Museum, 35:341-349.

Rathbun, M. J. 1915. Jacquinotia, a new crab name. Proceedings of the Biological Soicety of Washington, 28:142.

RATHBUN, M. J. 1918. Contributions to the geology and paleontology of the Canal Zone, Panama, and geologically related areas in Central America and the West Indies. Decapod crustaceans from the Panama Region. United States National Museum Bulletin 103:123-184, pls. $54-66$.

RAthBun, M. J. 1919. West Indian Tertiary decapod Crustaceans, p. 157184, pls. 1-9. In T. W. Vaughan (ed.), Contributions to the Geology and Paleontology of the West Indies. Carnegie Institution of Washington Publication 291. Gibson Brothers, Washington, DC.

Rathbun, M. J. 1920a. Additions to West Indian Tertiary decapod crustaceans. Proceedings of the Biological Society of Washington, 58:381384, pl. 25.

RAthBUN, M. J. 1920b. New species of spider crabs from the Straits of Florida and Caribbean Sea. Proceedings of the Biological Society of Washington, 33:23-24.

Rathbun, M. J. 1923. Fossil crabs from the Republic of Haiti. Proceedings of the United States National Museum, 63(article 9):1-6, pls. 1, 2

Rathbun, M. J. 1925. The Spider Crabs of America. United States National Museum Bulletin 129, 613 p.

Rathbun, M. J. 1935. Fossil Crustacea of the Atlantic and Gulf Coastal Plain. Geological Society of America Special Paper, Number 2:1-160.

Rathbun, M. J. 1937. Cretaceous and Tertiary crabs from Panama and Colombia. Journal of Paleontology, 11:26-28, pl. 5.

RAthBun, M. J. 1947. Phylum Arthropoda, p. 1-150. In M. M. Knechtel, E. F. Richards, and M. J. Rathbun (eds.), Mesozoic fossils of the Peruvian Andes. Johns Hopkins University Studies in Geology, 15.

RAUP, D. M. 1976. Species diversity in the Phanerozoic: An interpretation. Paleobiology, 2:289-297.
REMEš, M. 1895. Beiträge zur Kenntnis der Crustaceen der Stramberger Schichten. Bulletin International de l'Académie des Sciences de Bohème, 2:200-204, pls. 1-3.

Remy, J. M., AND F. Tessier. 1954. Décapodes nouveaux de la partie Ouest du Sénégal. Bulletin de la Société Géologique de France, 6(4): 185-191, pl. 11.

Reuss, A. E. 1857. Zur Kenntnis fossiler Krabben. Sitzungsberichte der Akademie der Wissenschaften, 27:161-166.

Reuss, A. E. 1859. Zur Kenntnis fossiler Krabben. Akademie der Wissenschaften Wien, Denkschrift 17:1-90, pls. 1-24

RüPPELL, E. 1830. Beschreibung und Abbildung von 24 Arten kurzschwänziger Krabben, als Beitrag zur Naturgeschichte des Rothen Meeres. Heinrich Ludwig Brönner, Frankfurt am Main, Germany, 28 p., pls. 1-6.

SAKAI, T. 1933. A new genus and some new species of crabs from Simoda. Science Reports of Tokyo Bunrika Daig, section B, 1:137-144.

Samouelle, G. 1819. The Entomologist's Useful Compendium, or an Introduction to the British Insects, etc. T. Boys, London, $496 \mathrm{p}$.

SAY, T. 1817-1818. An account of the Crustacea of the United States. Journal of the Academy of Natural Sciences of Philadelphia, 1(1)(1817):57-63, 65-80, 97-101, 155-169; (2)(1818):235-253, 313319, 374-401, 423-444, 445-458, pl. 4.

Schweitzer, C. E. 2001. Paleobiogeography of Cretaceous and Tertiary decapod crustaceans of the North Pacific Ocean. Journal of Paleontology, 75:808-826.

SCHWEITZER, C. E. 2003. Utility of proxy characters for classification of fossils: An example from the fossil Xanthoidea (Crustacea: Decapoda: Brachyura). Journal of Paleontology, 77:1107-1128.

Schweitzer, C. E. 2005. The genus Xanthilites Bell, 1858 and a new Xanthoid family (Crustacea: Decapoda: Brachyura: Xanthoidea): New hypotheses on the origin of the Xanthoidea MacLeay, 1838. Journal of Paleontology, 79(2):277-295.

Schweitzer, C. E., AND R. M. Feldmann. 2000a. Re-evaluation of the Cancridae Latreille, 1802 (Decapoda: Brachyura) including three new genera and three new species. Contributions to Zoology, 69:223-250.

Schweitzer, C. E., AND R. M. FeldManN. 2000b. New fossil portunids from Washington, USA, and Argentina, and a re-evaluation of generic and family relationships within the Portunoidea Rafinesque, 1815 (Decapoda: Brachyura). Journal of Paleontology, 74:636-653.

Schweitzer, C. E., And R. M. Feldmann. 2000c. First notice of the Chirostylidae (Decapoda) in the fossil record and new Tetiary Galatheidae (Decapoda) from the Americas. Bulletin of the Mizunami Fossil Museum, 27:155-173.

Schweitzer, C. E., AND R. M. Feldmann. 2001a. Differentiation of the fossil Hexapodidae Miers, 1886 (Decapoda, Brachyura) from similar forms. Journal of Paleontology, 75:330-345.

Schweitzer, C. E., AND R. M. FeldmanN. 2001b. New Cretaceous and Tertiary decapod crustaceans from western North America. Bulletin of the Mizunami Fossil Museum, 28:173-210.

Schweitzer, C. E., AND R. M. Feldmann. 2002. New Eocene decapods (Thalassinidea and Brachyura) from southern California. Journal of Crustacean Biology, 22:938-967.

Schweitzer, C. E., AND E. W. Salva. 2000. First recognition of the Chieragonidae Ortmann (Decapoda, Brachyura) in the fossil record and comparison of the family to the Atelecyclidae Ortmann (Decapoda, Brachyura). Journal of Crustacean Biology, 20:285-298.

Schweitzer, C. E., R. M. Feldmann, AND P. D. Gingerich. 2004. New decapods (Crustacea) from the Eocene of Pakistan and a revision of Lobonotus A. Milne Edwards, 1864. University of Michigan Contributions from the Museum of Paleontology, 31(4):89-118.

Schweitzer, C. E., R. M. Feldmann, G. GonzÁles-Barba, and F. J. VeGA. 2002. New crabs from the Eocene and Oligocene of Baja California Sur, Mexico and an assessment of the evolutionary and paleobiogeographic implications of Mexican fossil decapods. The Paleontological Society Memoir 59 (Supplement to Journal of Paleontology 76), $43 \mathrm{p}$.

Schweitzer, C. E., R. M. Feldmann, J. Fam, W. A. Hessin, S. W. Hetrick, T. G. Nyborg, AND R. L. M. Ross. 2003. Cretaceous and Eocene decapod crustaceans from southern Vancouver Island, British Columbia, Canada. NRC Research Press, Ottawa, Ontario, 66 p.

SCOTESE, C. R. 1997. Paleogeographic Atlas, PALEOMAP Progress Report 90-0497. Department of Geology, University of Texas at Arlington, $37 \mathrm{p}$.

SeCRETAN, S. 1964. Les Crustacés du Jurassique supérieur et Crétacé de 
Madagascar. Mémoires du Muséum national d'Histoire naturelle, $156(C): 1-223$.

SECRETAN, S. 1972. Crustacés Décapodes nouveaux du Crétacé supérieur de Bolivie. Bulletin du Muséum National d'Histoire Naturelle, third series, 49:1-15.

SeCretan, S. 1982. Xanthosia robertsi, Crustacé décapode du Crétacé de Madagascar: Nouveau nom et nouvelles hypothèses sur son origine. Geobios, 15:927-933.

SERÈnE, R., AND C. L. SoH. 1970. New Indo-Pacific genera allied to Sesarma Say, 1817 (Brachyura, Decapoda, Crustacea). Treubia, 27(4): 387-416, pls. $1-8$.

SOWERBY, J. 1826. Description of a new species of Astacus, found in a fossil state at Lyme Regis. Zoological Journal, 2:493-494.

StimPson, W. S. 1854-1857. On some California Crustacea. Proceedings of the California Academy of Natural Science (second edition), 1:188.

StIMPSON, W. S. 1858a. Prodromus descriptionis animalium evertebratorum, quae in Expeditione ad Oceanum Pacificum Septentrionalem, a Republica Federata missa, Cadwaladaro Ringgold et Johanne Ridgers Ducibus, observavit et descripsit. Pars V. Crustacea Ocypodoidea. Proceedings of the Academy of Natural Sciences of Philadelphia, 1858: 93-110.

Stimpson, W. S. 1858b. Prodromus descriptionis animalium evertebratorum, quae in Expeditione ad Oceanum Pacificum Septentrionalem, a Republica Federata missa, Cadwaladaro Ringgold et Johanne Ridgers Ducibus, observavit et descripsit. Pars IV. Crustacea Cancroidea et Corystoidea. Proceedings of the Academy of Natural Sciences of Philadelphia, 10:93-110.

StimPSON, W. S. 1859. Notes on North American Crustacea, No. 1. Annals of the Lyceum of Natural History of New York, 7(1862), no. 11: 49-93, $1 \mathrm{pl}$.

Stimpson, W. S. 1860. Notes on the North American Crustacea, in the Museum of the Smithsonian Institution. No. II. Annals of the Lyceum of Natural History, New York, 7:176-246, pls. 2, 5.

STIMPSON, W. 1866. Descriptions of new genera and species of macrurous Crustacea from the coasts of North America. Proceedings of the Chicago Academy of Sciences, 1:46-48.

Stimpson, W. 1871. Preliminary report on the Crustacea dredged in the Gulf Stream in the Straits of Florida, by L. F. Pourtales, Assist. U.S. Coast Guard Survey. Bulletin of the Museum of Comparative Zoology, Harvard University, 2:109-160.

StoliczKA, F. 1871. Observations of fossil crabs from Tertiary deposits in Sind and Kutch. Memoirs of the Geological Survey of India, Palaeontologica Indica, series 7, XIV, vol. 1, pt. 1, 16 p., 5 pls.

TAYLOR, B. J. 1979. Macrurous Decapoda from the Lower Cretaceous of south-eastern Alexander Island. British Antarctic Survey, Scientific Reports, No. 81, 39 p.

TshUDY, D., AND L. E. BABCOCK. 1997. Morphology-based phylogenetic analysis of the clawed lobsters (family Nephropidae and the new family Chilenophoberidae). Journal of Crustacean Biology, 17:253-263.

Tshudy, D. M., AND R. M. FeldmanN. 1988. Macruran decapods, and their epibionts, from the López de Bertodano Formation (Upper Cretaceous), Seymour Island, Antarctica, p. 291-301. In R. M. Feldmann and M. O. Woodburne (eds.), Geology and Paleontology of Seymour Island, Antarctic Peninsula. Geological Society of America Memoir, 169.

TUCKER, A. B. 1998. Systematics of the Raninidae (Crustacea: Decapoda: Brachyura), with accounts of three new genera and two new species. Proceedings of the Biological Society of Washington, 111:320-371.

VaIL, P. R., R. M. Mitchum JR., AND S. Thompson III. 1977. Seismic stratigraphy and global changes of sea level, part 4: Global cycles of relative changes of sea level, p. 83-97. In C. E. Payton (ed.), Seismic Stratigraphy-Applications to Hydrocarbon Exploration. American Association of Petroleum Geologists, Memoir 26, Tulsa, Oklahoma.

van Bakel, B. W. M., J. W. M. Jagt, R. H. B. FraaiJe, and Y. Coole. 2003. New data on the crab Binkhorstia ubaghsii (late Maastrichtian); NE Belgium, SE Netherlands). Contributions to Zoology, 72:85-89.

VAn Straelen, V. 1924 [1925]. Contribution à l'étude des crustacés décapodes de la période jurassique. Memoires d'Academie Royale de Belgique, Classe des Sciences, collected in number 4, series 2, 7:1462 , pls. $1-10$.

Van Straelen, V. 1933. Sur les Crustacés Décapodes Cenozoiques du Venezuela. Bulletin du Musée Royal d'Histoire Naturelle de Belgique, IX, no. 9:1-11.
Vega, F. J., ANd M. Del Carmen Perrilliat. 1989. Una especie nueva de cancrejo del género Costacopluma (Crustacea: Decapoda: Retroplumidae) del Maastrichtiano de Nuevo León, México. Universidad Nacional Autonoma, Instituto de Geología, revista, 8:84-87.

Vega, F. J., AND R. M. Feldmann. 1992. Occurrence of Costacopluma (Decapoda: Brachyura: Retroplumidae) in the Maastrichtian of southern Mexico and its paleobiogeographic implications. Annals of Carnegie Museum, 61:133-152.

Vega, F. J., R. M. Feldmann, A. C. Ocampo, and K. O. Pope. 1997. A new species of Late Cretaceous crab (Brachyura: Carcineretidae) from Albion Island, Belize. Journal of Paleontology, 71:615-620.

VIA, L. 1966. Pinnixa (Palaeopinnixa) mytilicola, nuevo braquiuro fósil, en el mioceno marino del Vallés (Barcelona). Acta Geologica Hispanica, 1:1-4.

vON MeYer, H. 1835. Briefliche Mitteilungen. Neues Jahrbuch für Mineralogie, Geologie, und Paläontologie, 1835:328.

von Meyer, H. 1840. Briefliche Mitteilungen. Neues Jahrbuch für Mineralogie, Geologie, und Paläontologie, 1840:587.

von MeYer, H. 1860. Die Prosoponiden oder die Familie der Maskenkrebse. Palaeontographica (Stuttgart), 7:183-222, pl. 23.

WeBER, F. 1795. Nomenclator entomologicus secundum Entomologiam Systematicum ill. Fabricii adjectis speciebus recens detectis et varietatibus. Carolum Ernestum Bohn, Chilonii and Hamburgi, Germany, 171 p.

Weller, S. 1903. The Stokes collection of Antarctic fossils. Journal of Geology, 11:413-419.

WHITE, A. 1842. Description of an orthopterous insect, and two new species of Crustacea, from New Zealand in the collection of the British Museum, p. 78-79. In J. E. Gray (ed.), Zoological Miscellany, 18311844. E. Nodder and Son, London.

White, A. 1846 [1847]. Short description of some new species of Crustacea in the collection of the British Museum. Annals and Magazine of Natural History, 20:205-207.

White, A. 1852. Descriptions of some new species of Annulosa, p. 387395. In J. Macgillivray (ed.), Narrative of the Voyage of H. M. S. "Rattlesnake" During the Years 1846-1850, vol. 2, appendix. Boone, London.

White, A. 1856. Some remarks on Crustacea of the genus Lithodes with a brief description of a species apparently hitherto unrecorded. Proceedings of the Zoological Society of London, 1856:132-135, pl. 42.

WhitEAVES, J. F. 1874. On recent deep-sea dredging operations in the Gulf of St. Lawrence. American Journal of Science, series 3, 7:210-219.

WiLCKENS, O. 1907. Die Llamellibranchiaten, Gastropoden U.S.W. der oberen Kreide Südpatagoniens. Berichte der Naturforschenden Gesellschaft zu Freiburg i Braunschweig, 15:97-166.

WintLE, S. H. 1886. Notes on fossil crabs from the deep dredgings of the Yarra River, and excavation of the Coode Canal, Victoria. Papers and Proceedings of the Royal Society of Tasmania, 1886:233-234.

WiTHERS, T. H. 1922. On a new brachyurous crustacean from the Upper Cretaceous of Jamaica. Annals and Magazine of Natural History, 9, 10:534-541.

Wood-Mason. J. 1875. On the genus Deidamia Willemoes-Suhm. Annals and Magazine of Natural History, 4(15):131-135.

Woods, H. 1922. Crustacea from the Eocene deposits of Peru, p. 114118. In T. O. Bosworth (ed.), Geology of the Tertiary and Quaternary Periods in the Northwest Part of Peru. Macmillan, London.

Woods, J. T. 1953. Brachyura from the Cretaceous of central Queensland. Memoirs of the Queensland Museum, 13(1):50-57.

Woods, J. T. 1957. Macrurous decapods from the Cretaceous of Queensland. Memoirs of the Queensland Museum, 13(3):155-175, pls. IV-VI.

WOODWARD, H. 1867. On a new species of shore-crab, Goniocypoda Edwardsi, from the lower Eocene of Hampshire. Geological Magazine, 4:529-531.

WoOdward, H. 1876. On a new fossil crab from the Tertiary of New Zealand, collected by Dr. Hector, F.R.S., F.G.S., Director of the Geological survey of New Zealand. Quarterly Journal of the Geological Society of London, 32:51-56.

Woodward, H. 1892. Note on a new decapodous crustacean (Prosopon Etheridgei H. Woodw.) from the Cretaceous of Queensland, Australia. Proceedings of the Linnaean Society of New South Wales, ser. 2, 7: 301-306.

WoOdWARD, H. 1903. On some fossil prawns from the Osborne Beds of the Isle of Wight. Geological Magazine, 10:97-99, pl. 5. 
Wright, C. W. 1997. New information on Cretaceous crabs. Bulletin of the Natural History Museum, London, 53:135-138.

ZINSMEISTER, W. J. 1979. Biogeographic significance of the Late Mesozoic and Early Tertiary molluscan faunas of Seymour Island (Antarctic Peninsula) to the final breakup of Gondwanaland, p. 349-355. In J. Gray and A. Boucot (eds.), Historical Biogeography, Plate Tectonics and the Changing Environment. Proceedings of the $37^{\text {th }}$ Annual Biology Colloquium and Selected Papers, Oregon State University Press, Corvallis.
ZINSMEISTER, W. J. 1982. Late Cretaceous-Early Tertiary molluscan biogeography of the southern circum-Pacific. Journal of Paleontology, 56: 84-102.

Zinsmeister, W. J., AND R. M. Feldmann. 1984. Cenozoic high latitude heterochroneity of Southern Hemisphere marine faunas. Science, 224: 281-283.

ZitTel, K. A. von. 1885. Handbuch der Paläontologie. Vols. 1, 2. Abt. R. Oldenbourg, München, p. 679-721.

ACCEPTEd 24 August 2004 